\title{
Electrocutions of Bids on Power Lines in the Altail Kray (Russia) in 2021
}

\section{ГИБЕЛЬ ПТИЦ НА ЛЭП В АЛТАЙСКОМ КРАЕ (РОССИЯ) В 2021 ГОДУ}

\author{
Shnayder E.P. (Sibecocenter LLC, Novosibirsk, Russia) \\ Шнайдер Е.П. (ООО «Сибэкоцентр», Новосибирск, Россия)
}

\section{Контакт: \\ Елена Шнайьер \\ ООО «Сибэкоцентр» \\ Россия 630090 \\ Новосибирск, а/я 547 \\ тел.: +79137956549 \\ equ001@gmail.com}

\section{Contact:}

Elena Shnayder

LLC Sibecocenter

P.O. Box 547, Novosibirsk

Russia 630090

tel.: +79137956549

equ001@gmail.com

\section{Резюме}

В сентябре 2021 г. были обследованы 126 км 6-10 кВ линий электропередачи в разнообразных биотопах Алтайского края - от ленточных боров Ао предгорий. Из обследованных линий, 27,94 км суммарно были оборудованы ПзУ. Во время проверки были обнаружены 515 особей погибших птиц. Из них хишные птицы составляли 21\%, а виды, внесённые в Красную книгу РФ, - 1,94\%. Плотность фрактической гибели птиц составила 5,6 ос./км, только мия хищных - 1,18 ос./км. Фактический ушерб, причинённый объектам животного мира, оценён в 6,1 млн. руб. Фактический ушерб, нанесённый одной опорой, - в 3925 руб. Оценка вероятного уровня гибели птиц на осмотренных участках ПО АЭП за весь миграционно-гнездовой сезон составила 8,63ос./км. Аппроксимация на условную обшую протяжённость ПО АЭП А^тайского края Ааёт оценку гибели птиц в 50,7 тыс. особей за период с апреля по октябрь. Максимальный уровень гибели птиц наблюдается на ПО ^ЭП, идуших через открытые ненарушенные биотопы. Также отмечен повышенный уровень гибели птиц на анкерных и угловых опорах по сравнению с промежуточными. Суммарно мля всех видов птиц превышение составляет 2,9 раза, а Аля хишных птиц - 4,9 раза.

КАючевые слова: хишные птицы, пернатые хишники, ^ЭП, поражение электротоком, А^тайский край. Поступима в рехакцию: 20.12.2021 г. Принята к публикации: 28.12.2021 г.

\section{Abstract}

In September 2021, 126 km of 6-10 kV power lines were surveyed in Altai Kray, Russia. The survey encompassed different types of habitat from pine forests to the foothills of Altai mountains. Out of $126 \mathrm{~km}, 27.94 \mathrm{~km}$ of power lines were equipped with bird-protection devices to prevent bird death from electrocution. We uncovered 515 cases of bird death on unsafe lines. Raptors make $21 \%$ and endangered species $-1.94 \%$. The density of dead birds was equal to 5.6 ind./ $\mathrm{km}$ of non-safe power lines, and of raptors $-1.18 \mathrm{ind} . / \mathrm{km}$. The observed damage to the ecosystem was estimated as 6.1 million of Rub (equal to \$ 83,350 or $€ 73,600$ ), and the damage calculated per one electric pole was 3,925 Rub. The estimation of the death rate of birds on the observed length of power lines through the whole migration and breeding seasons makes 8.63 ind./ $\mathrm{km}$. Approximation to the presumptive total length of bird unsafe power lines in the Altai Kray makes 50,700 birds possibly die every year in the region from April till October. The highest level of bird mortality was observed on power lines stretching through open undisturbed habitats (i.e. steppe biotope). We also noted 2.9 times higher mortality on push brace poles compared with intermediate ones for all species, and 4.9 times higher for raptors only.

Keywords: birds of prey, raptors, power lines, electrocution, Altai Kray.

Received: 20/12/2021. Accepted: 28/12/2021.

\section{Введение}

На территории А^тайского края широко представлены степные холмисто-увамистые ландшафрты, также характерной чертой являются менточные боры, протянувшиеся межАу Иртышом и Обью. Эти биотопы яв^яются оптимальными А^я гнездования пернатых хишников, а также мля их охоты на мелкую и среднеразмерную $о$ обычу. По предгорной части края проходит широкий миграционный коримор степных орлов (Aquila nipalensis), ^етяших на зимовки из Минусинской котловины (Карякин и мр., 2019; RRRCN, 2021a; 2021b), а также орлов-могильников (Aquila heliaca). Через степную часть края, полностью преобразованную в сельскохозяйственные ландшафрты, мигрирует большое количество канюков (Buteo buteo). Характерными гнездяшимися обитателями края яв^яются такие редкие вилы, внесённые в Красную книгу России, как беркут (Aquila chrysaetos), орёл-могильник, степной орёл,

\section{Introduction}

Altai Kray has a spreading steppe, agricultural and hilly biotopes, and its peculiar character is pine forests growing on stripe-shaped sandy patches stretching through several hundred kilometers - remains of an ancient glacier. They present perfect habitats for birds of prey and owls for nesting and hunting. Along the foothills of Altai mountains lays a vast migration flyway of eagles that come from northern and eastern regions in autumn (Karyakin et al., 2019; RRRCN, 2021a; 2021b). Steppe and agricultural parts of the region are popular among migrating Buzzards (Buteo SP). Among breeding species of the region, there are many endangered raptors like Golden Eagle (Aquila chrysaetos), Eastern Imperial Eagle (Aquila heliaca), Steppe Eagle (Aquila nipalensis), Greater Spotted Eagle (Clanga clanga), White-Tailed Eagle (Haliaeetus albicilla), Peregrine (Falco peregrinus), and Eagle Owl (Bubo bubo) (Karyakin et al., 2005; Smelyanskiy, Tomilenko, 2005; Vazhov, 2012). For all of them, elec- 
большой подорлик (Aquila clanga), орланбелохвост (Haliaeetus albicilla), сапсан (Falco peregrinus), фрилин (Bubo bubo) (Карякин и мр, 2005; Смелянский, Томиленко, 2005; Важов, 2012).

$\triangle \wedge я$ всех вышеперечисленных видов хишных птиц воздушные линии электропередачи (^ЭП), сконструированные на железобетонных опорах с заземлёнными метамлическими траверсами, оснашёнными штыревыми изоляторами с голым проводом, несут повышенную угрозу ввиду их привлекательности посреди открытых биотопов в качестве присад. Птица, садя-

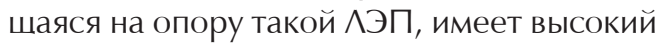
риск поражения электротоком в результате замыкания электроцепи при одновременном касании заземлённой траверсы и токонесушего провода (Салтыков, 2014). Проблема эта обшеизвестна во всём мире (Lehman et al., 2007; Карякин, 2012; Loss et al., 2014; Пуликова, Воронова, 2018), и мля нейтрализации фрактора гибели птиц на ^ЭП от поражения электротоком прилагаются серьёзные усилия на межлународном уровне (Prinsen et al., 2012).

Первое обследование АЭП в А^тайском крае на предмет выявления птицеопасных конструкций (Аалее ПО АЭП) и определения уровня гибели хишных птиц на них с целью подготовки рекомендаций по оснашению этих АЭП птицезашитными устрой-

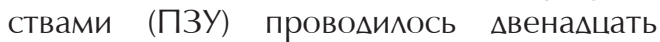
лет назал - в 2009 г. Были обследованы АЭП, идушие вАОль ленточных боров А^тая - Касмалинской и Барнаульской мент, а также в предгорьях Северо-Западного А^тая - всего 123,4 км ^ЭП в пределах А^тайского края; оценка средней плотности гибели птиц составила 5,15ос./км АЭП в гнезАовой периол и 2,45ос./км АЭП осенью (Карякин и мр., 2009). По результатам этих исследований в аАрес МРСК Сибири и компаний мобильной связи (Билайн, Мегафрон и МТС) были направлены рекоменАации по оснашению обследованных АЭП ПЗУ (Николенко, Карякин, 2012).

В Аанной работе были проверены новые участки птицеопасных АЭП, появившихся в крае за 10 лет, а также перепроверены те, которые $А$жжны были быть оснашены ПЗУ по результатам прошлой проверки. Работа затронула 14 районов Алтайского края - Павловский, Ребрихинский, Мамонтовский, Романовский, Волчихинский, Новичихинский, Поспелихинский, Курьинский, Красношёковский, УстьКалманский, Чарышский, Петропав^овский, Усть-Пристанский, Топчихинский. trocution on unsafe power lines with pin insulators, bare wire, and grounded metal crossarms (Saltykov, 2014) is an important threat since electric poles are considered by raptors as a convenient perching site in open landscapes. This problem is well known over the world (Lehman et al., 2007; Karyakin, 2012; Loss et al., 2014; Pulikova, Voronova, 2018), and serious efforts are being made on the international level to solve it (Prinsen et al., 2012).

The first survey of power lines in Altai Kray was conducted in 2009. In total $123.4 \mathrm{~km}$ were surveyed in the region. The average density of bird mortality was $5.15 \mathrm{ind} . / \mathrm{km}$ during the breeding season and $2.45 \mathrm{ind} . / \mathrm{km}$ during fall migration (Karyakin et al., 2009). Besides, in the same study power lines of the Altai Republic were also surveyed. Based on the result of the study, recommendations for retrofitting unsafe power lines with bird-protection devices were sent to the power line owners - grid and cellular companies (Nikolenko, Karyakin, 2012).

In the present study, we surveyed new stretches of unsafe power lines constructed in the region for 10 years and re-surveyed those that were to be retrofitted with bird-protection devices (BPDs) under the agreement concluded with power grid companies after the initial check in 2009. Fieldwork encompassed 14 districts of Altai Kray with all its main habitats - woodlands, steppe, agricultural fields, and mountain foothills. We assess the current rate of bird mortality caused by electrocution; the damage done to the ecosystem due to maintaining unsafe aerial power lines; the effectiveness of measures implemented by power line owners under the agreement of 2009. At the end of the article, our suggestions to minimize the damage are listed.

\section{Methods}

Fieldworks were conducted from 15 to 30 of September 2021. Survey routes run through open habitats along pine forests and mountain foothills. Lines that stretch inside woodlands were not among the targets of this study since they possess less danger to birds compared to lines in open habitats. We checked medium voltage (6-10 kV) power lines (PL) with bare wire and pin insulators on concrete poles (fig. 1). Lines on wooden poles and lines with insulated wire were not checked. In a few cases $(n=3)$, renovated concrete poles were detected by accident in wooden lines and checked. Most of these lines were identified during fieldwork in 2015-2020 during a routine raptor survey. 
Рис. 1. Примеры осмотренных опор: $A$ и $B$ промежуточные бетонные опоры со штыревыми изоляторами, C - угловая бетонная опора со штыревыми изоляторами. Фото Е. Шнайдер.

Fig. 1. Examples of surveyed poles. $A$ and $B$ intermediate concrete poles with pin insulators and bare wire; $C$ - Push brace concrete pole with pin insulators and bare wire. Photos by E. Shnayder.
Таким образом, были обследованы и боровые, и предгорные, и полевые биотопы. Проведена оценка исполнения принятых планов оснашения ^ЭП птицезашитными устройствами (ПЗУ), Аана оценка того, насколько сильно изменилась ситуация с гибелью птиц на ^ЭП за Аесять ^ет, посчитан ушерб от незаконной эксплуатации ^ЭП, не оснашённых ПЗУ, а также $а$ аны пред^ожения по минимизации ушерба.

\section{Методика}

Полевые работы велись на территории Пав^овского, Ребрихинского, Мамонтовского, Романовского, Волчихинского, Новичихинского, Поспелихинского, Курьинского, Красношёковского, Усть-Камманского, Чарышского, Петропавловского, УстьПристанского, Топчихинского районов Алтайского края 15-30 сентября 2021 г. Маршруты были проложены по открытым местообитаниям, ихушим воль боровых лент или предгорий. Аинии, проходяшие по просекам внутри боров и в облесённых местообитаниях, слабо были охвачены наблюдениями, поскольку они представляют меньшую опасность ввиду наличия в бору множества альтернативных мест мля посалки птиц. Обследовались участки ПО ^ЭП средней мошности (6-10 кВ), преимушественно на бетонных опорах со штыревыми изоляторами (рис. 1). Участки на меревянных опорах, представляюшие сушественно меньшую опасность $\Delta \wedge я$ птиц, а также минии на СИП-3 не осматривались. В единичных случаях были осмотрены анкерные бетонные опоры в деревянных ^ЭП и деревянные анкерные опоры с минейными разъединителями. Такие опоры учтены поштучно. Большинство осмотрен-
We used the same survey method as in 2020 in Khakassia, Russia detailed in Shnayder et al., 2020. The survey was conducted from the slowly moving $4 \times 4$ off-road vehicle. Poles surrounded by high grass or bushes were thoroughly checked on foot. Lines running through swamps and woodlands were also checked on foot. The whole survey route and locations of each dead bird found were recorded via mobile application LocusPRO ${ }^{19}$. Every dead bird and a pole that caused death were photographed, and the full set of photos is attached as supplementary files (PDF) ${ }^{21}$. Collected data was input in the web-GIS database "Protected areas and anthropogenic threats $^{\prime 20}$. Catalog of power lines also is attached as supplementary $(. x \mid s x)^{22}$. All raptor remains were sampled for the feather collection, which could be used for DNA or contamination studies (sharing, collab, details on request). Species ID to species or genus was done on a spot. The term of death of each carcass was evaluated by visual marks (method detailed in Shnayder et al., 2020).

In total, we surveyed 48 stretches of different power lines with a total length of $126 \mathrm{~km}$, plus three single unsafe concrete poles in bird-safe wooden lines (table 1, fig. 2). A part of them $(28 \mathrm{~km})$ was equipped with bird-protection devices.

To calculate the amount of damage to the ecosystem, we used methods and formulas prescribed by enactments of the Russian Federation concerning species enlisted in the Red List, game species, and non-game species (The Methodology..., 2008; The Methodology..., 2011). The inflation rate (IR) was calculated by December of 2021 and makes IR $=2.63$ (Inflation in Russia, 2020). For the game species, the multiplier coefficient $(K)$ was set as $K=3$

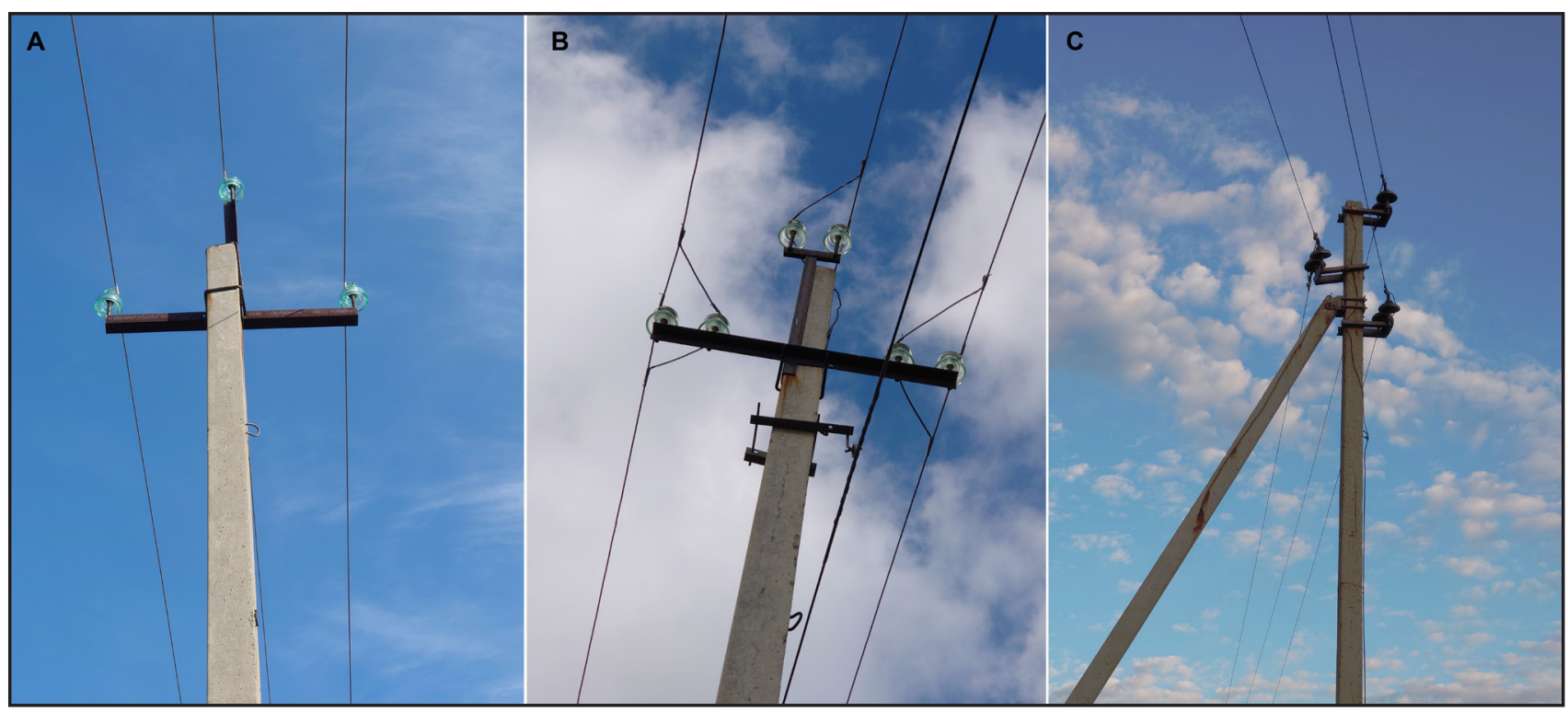


ных ^ЭП было выявлено с 2015 по 2021 годы в ходе полевых работ, целью которых яв^ялся мониторинг мест гнездования редких виАОв хишных птиц.

В Аанной работе применялась методика, описанная в статье 2020 г. по результатам исследований в Хакасии (Шнайлер и мр., 2020). Осмотр АЭП осушествлялся из окон Авижушейся в ОАь АЭП на низкой скорости машины, участки с высоким растительным покровом тшательно осматривались во время остановки автомобиля - с раздвиганием травы около опор и проверкой растуших под опорами кустов. Заболоченные и лесные участки проверялись на пеших маршрутах. Весь маршрут фриксирова^ся в GIS-приложении LocusPRO ${ }^{19}$ м^я мобильного телефрона, отмечались места обнаружения птичьих останков, нача^о и конец птицеопасных участков. Производилась фоотофиксация останков птиц. $\triangle$ анные внесены в раздел «ООПТ и антропогенные угрозы» ${ }^{20}$ веб-ГИС «Фаунистика». Полный фротореестр птиц, погибших на $\Lambda Э П$, в орормате PDF ${ }^{21}$, а также реестр ^ЭП в фрормате MS EXCEL ${ }^{22}$ прилагаются к статье в виле Аополнительных фрайлов. Со всех перьевых останков хишных птиц были скомектировны образцы перьев. Видовая приналлежность всех останков была опремелена $а$ в вила или рода. Оценивался срок Аавности гибели птицы.

Всего было осмотрено 48 участков пти-

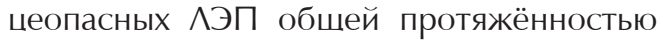
126 км и ешё три отлельно стояшие птицеопасные опоры в условно-безопасных миниях (табл. 1, рис. 2). Среди проверенных АЭП абсолютно преоблаАали кинии на бетонных опорах с неизолированными проводами. Часть из этих миний были оснашены ПЗУ - всего 28 км.

$\Delta \wedge я$ исчисления размера вреда видам, внесённым в КК, а также иным вилам, не относяшимся К охотничьим ресурсам, были взяты нормативы стоимости из При^ожения 2 к Методике исчисления размера вреда, причинённого объектам животного мира, занесённым в Красную книгу РФ (Метолика..., 2008), а также фрормула расчёта, указанная в Методике. Коэфорициент инорляции был рассчитан на ноябрь 2021 гола в размере КИ=2,63 (уровни инфряяции с 2008 по 2021 годы взяты из Аанных, опубликованных на сайте «Инфрляция в России» (2021). under paragraph 1.5 (extermination of the game caused by economic activity).

During the survey, we recorded observations of live raptors in the close vicinity of power lines under study.

\section{Results and discussion}

On the surveyed power lines, we found 515 dead birds of 23 species in total. Among them, 108 dead birds (21\%) are raptors of 11 species, and 10 dead birds (1.94\%) of 6 species are enlisted in the Red List of Russia, namely Eagle Owl - 2 ind., Peregrine - 2 ind., Long-Legged Buzzard (Buteo rufinus) - 2 ind., Steppe Eagle - 1 ind., Greater Spotted Eagle - 1 ind., Pallid Harrier (Circus macrourus) - 1 ind., and one eagle who's old remains were not possible to ID up to species (Aquila SP/ Clanga clanga) (fig. 3, table 1).

The average density of dead birds per $1 \mathrm{~km}$ of surveyed length of power lines is 4.1 ind./ $\mathrm{km}$, and for raptors -0.86 ind./ $\mathrm{km}$. But if we exclude from the total length de-energized lines and lines fully equipped with BPDs, i.e. safe power lines, then the real density of bird mortality on the rest $91.8 \mathrm{~km}$ of unsafe power lines (UPL) would be 5.6 ind./ $/ \mathrm{km}$ in total and $1.18 \mathrm{ind} . / \mathrm{km}$ for raptors only.

The amount of damage to the ecosystem calculated by the actual number of dead birds found makes 6,125,435 Rub (equal to $\$ 83,350$ or $€ 73,600$ ) (table 2). The main input was done by 10 specimens enlisted in the Red List of Russia. Figure 4 depicts the proportion of endangered species, non-endangered raptor species, and other species in the dead birds found, and the input of each group into the calculated damage to the ecosystem.

Since most cases of bird mortality occur on $91.8 \mathrm{~km}$ of unsafe power lines, we can calculate the average damage caused by one electric pole considering that the number of poles in $1 \mathrm{~km}$ of a line is 17 (Shnayder et al., 2020). Thus, the damage per one pole is 3,925 Rub.

In the previous papers (Karyakin et al., 2009; Shnayder et al., 2020), we divided power lines by surrounding biotopes to reveal that the most dangerous ones are those stretching through open undisturbed habitats, and the less dangerous ones are power lines running along highways and country lanes. In the present work we got the same result comparing bird mortality on (1) roadside power lines, (2) power lines surrounded by undisturbed open habitats - "steppe" type, and (3) power lines

\footnotetext{
9 http://www.locusmap.app

20 http://oopt.wildlifemonitoring.ru

21 http://rrrcn.ru/wp-Content/uploads/2021/12/Photorep_LEP-2021.pdf

22 http://rrrcn.ru/wp-content/uploads/2021/12/LEP-2021.xIsX
} 


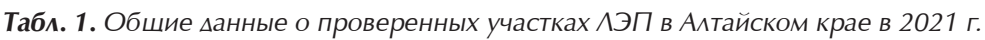

Table 1. Summary of data obtained during the examination of power lines in Altai Kray, Russia, in 2021.

\begin{tabular}{|c|c|c|c|c|c|c|c|c|}
\hline $\begin{array}{l}\text { Индекс } \\
\text { Index } \\
\end{array}$ & $\begin{array}{l}\text { Алина, } \\
\text { км } \\
\text { Length, } \\
\text { km } \\
\end{array}$ & $\begin{array}{r}\text { Погибшие } \\
\text { птицы, ос. } \\
\text { Electrocuted } \\
\text { birds (EB), ind. } \\
\end{array}$ & $\begin{array}{r}\text { Погибшие } \\
\text { хишные птицы, } \\
\text { oc. / Electrocuted } \\
\text { raptors (ER), ind. } \\
\end{array}$ & $\begin{array}{r}\text { Плотность гибели } \\
\text { птиц, ос. } / 1 \text { км } \\
\text { Density of EB, } \\
\text { ind./1 km } \\
\end{array}$ & $\begin{array}{r}\text { Плотность гибели } \\
\text { хишных птиц, } \\
\text { oc./1 кM / Density } \\
\text { of ER, ind./1 km } \\
\end{array}$ & $\begin{array}{r}\text { Число } \\
\text { вимов птиц } \\
\text { No of bird } \\
\text { species } \\
\end{array}$ & $\begin{array}{r}\text { Число видов } \\
\text { хишных птиц } \\
\text { No of raptor } \\
\text { species } \\
\end{array}$ & $\begin{array}{r}\text { Tип } \\
\text { Type } \\
\end{array}$ \\
\hline 1 & 2 & 3 & 4 & 5 & 6 & 7 & 8 & 9 \\
\hline$\wedge 1$ & 4 & 17 & 1 & 4.3 & 0.25 & 5 & 1 & $\mathrm{R}$ \\
\hline$\wedge 2 a$ & 0.5 & 1 & 0 & 2 & 0 & 1 & 0 & $\mathrm{R}$ \\
\hline$\wedge 2 \mathrm{~B}$ & 1.5 & 0 & 0 & 0 & 0 & 0 & 0 & W \\
\hline$\wedge 3$ & 0.8 & 6 & 0 & 7.5 & 0 & 3 & 0 & $\mathrm{R}$ \\
\hline$\wedge 4$ & 0.8 & 3 & 0 & 3.8 & 0 & 2 & 0 & $\mathrm{R}$ \\
\hline$\wedge 5$ & 1.3 & 11 & 5 & 8.5 & 3.85 & 5 & 2 & $\mathrm{R}$ \\
\hline$\wedge 6$ & 4.5 & 29 & 10 & 6.4 & 2.22 & 9 & 4 & $\mathrm{~F}$ \\
\hline$\Lambda 7$ & 1.7 & 5 & 1 & 2.9 & 0.59 & 4 & 1 & $\mathrm{R}$ \\
\hline$\wedge 8$ & 2.3 & 30 & 7 & 13 & 3.04 & 6 & 2 & $S$ \\
\hline$\wedge 9^{* * *}$ & 1.7 & 2 & 0 & 1.2 & 0 & 2 & 1 & $\mathrm{R}^{* * *}$ \\
\hline$\wedge 10$ & 3.2 & 33 & 3 & 10 & 0.94 & 7 & 1 & S \\
\hline$\wedge 11$ & 2 & 17 & 3 & 8.5 & 1.5 & 7 & 2 & $\mathrm{R}$ \\
\hline$\wedge 12$ & 1.4 & 16 & 2 & 11 & 1.43 & 6 & 2 & $\mathrm{R}$ \\
\hline$\wedge 13$ & 8.6 & 86 & 38 & 10 & 4.42 & 13 & 7 & S \\
\hline$\wedge 15$ & 1.6 & 11 & 1 & 6.9 & 0.63 & 5 & 1 & $\mathrm{R}$ \\
\hline$\wedge 16^{*}$ & 1.5 & 0 & 0 & 0 & 0 & 0 & 0 & $\mathrm{~S}^{*}$ \\
\hline$\wedge 17$ & 1.1 & 22 & 2 & 20 & 1.82 & 7 & 2 & $S$ \\
\hline$\wedge 18$ & 0.27 & 4 & 0 & 15 & 0 & 2 & 0 & S \\
\hline$\wedge 19^{* *}$ & 0.56 & 3 & 0 & 5.4 & 0 & 1 & 0 & $\mathrm{R}$ \\
\hline$\wedge 20$ & 7.2 & 55 & 7 & 7.6 & 0.97 & 7 & 3 & S \\
\hline$\wedge 21$ & 0.37 & 3 & 0 & 8.1 & 0 & 2 & 0 & S \\
\hline$\wedge 22^{*}$ & 5.4 & 0 & 0 & 0 & 0 & 0 & 0 & $\mathrm{R}^{*}$ \\
\hline$\wedge 23 a$ & 1.62 & 4 & 3 & 2.5 & 1.85 & 2 & 1 & S \\
\hline$\wedge 23 b$ & 1.2 & 2 & 1 & 1.7 & 0.83 & 2 & 1 & $\mathrm{R}$ \\
\hline$\wedge 23 \mathrm{c}$ & 1.3 & 21 & 2 & 16 & 1.54 & 6 & 2 & $\mathrm{~T}$ \\
\hline$\wedge 27$ & 1.2 & 4 & 1 & 3.3 & 0.83 & 3 & 1 & $\mathrm{R}$ \\
\hline$\wedge 28$ & 0.4 & 1 & 1 & 2.5 & 2.5 & 1 & 1 & $\mathrm{~F}$ \\
\hline$\wedge 29$ & 0.3 & 5 & 1 & 17 & 3.33 & 4 & 1 & $\mathrm{R}$ \\
\hline$\wedge 30$ & 0.09 & 2 & 0 & 22 & 0 & 1 & 0 & $\mathrm{R}$ \\
\hline$\wedge 31^{* *}$ & 7.52 & 21 & 3 & 2.8 & 0.4 & 6 & 2 & $\mathrm{R}$ \\
\hline$\wedge 32$ & 0.3 & 3 & 1 & 10 & 3.33 & 2 & 1 & $\mathrm{R}$ \\
\hline$\wedge 33$ & 0.3 & 3 & 2 & 10 & 6.67 & 3 & 2 & $\mathrm{R}$ \\
\hline$\wedge 34$ & 0.3 & 0 & 0 & 0 & 0 & 0 & 0 & $\mathrm{R}$ \\
\hline$\wedge 35$ & 7.22 & 16 & 4 & 2.2 & 0.55 & 10 & 4 & $\mathrm{~F}$ \\
\hline$\wedge 36$ & 0.26 & 0 & 0 & 0 & 0 & 0 & 0 & $\mathrm{R}$ \\
\hline$\wedge 37$ & 1.1 & 4 & 2 & 3.6 & 1.82 & 3 & 2 & $\mathrm{~F}$ \\
\hline$\wedge 38$ & 1.2 & 3 & 1 & 2.5 & 0.83 & 2 & 1 & $\mathrm{~F}$ \\
\hline$\wedge 39 a^{* *}$ & 12.1 & 22 & 2 & 1.8 & 0.17 & 6 & 2 & $\mathrm{~F}$ \\
\hline$\wedge 39 b$ & 3.4 & 11 & 2 & 3.2 & 0.59 & 6 & 2 & $\mathrm{R}$ \\
\hline$\wedge 39 / 1-3$ & 0.71 & 2 & 0 & 2.8 & 0 & 2 & 0 & $\mathrm{R}$ \\
\hline$\wedge 40^{* * *}$ & 9.5 & 0 & 0 & 0 & 0 & 0 & 0 & $\mathrm{~F}^{* * *}$ \\
\hline$\wedge 42$ & 0.23 & 2 & 0 & 8.7 & 0 & 1 & 0 & $\mathrm{R}$ \\
\hline$\wedge 43$ & 0.68 & 0 & 0 & 0 & 0 & 0 & 0 & $\mathrm{R}$ \\
\hline$\wedge 44 a^{*}$ & 16 & 7 & 0 & 0.4 & 0 & 2 & 0 & $\mathrm{R}^{*}$ \\
\hline$\wedge 44 \mathrm{~b}$ & 0.92 & 7 & 0 & 7.6 & 0 & 3 & 0 & $\mathrm{R}$ \\
\hline$\wedge 47$ & 2 & 12 & 0 & 6 & 0 & 4 & 0 & $\mathrm{~F}$ \\
\hline$\wedge 48$ & 1.7 & 3 & 1 & 1.8 & 0.59 & 3 & 1 & $\mathrm{~S}$ \\
\hline
\end{tabular}


Табл. 1. Обшие Аанные о проверенных участках АЭП в А^тайском крае в 2021 г. (окончание).

Table 1. Summary of data obtained during the examination of power lines in Altai Kray, Russia, in 2021 (Ending).

\begin{tabular}{|c|c|c|c|c|c|c|c|c|c|}
\hline 1 & 2 & 3 & 4 & 5 & 6 & 7 & 8 & & 9 \\
\hline$\wedge 49$ & 2 & 0 & 0 & 0 & 0 & 0 & & 0 & $\mathrm{R}$ \\
\hline опора A & 0 & 3 & 0 & & & & & & \\
\hline опора Б & 0 & 1 & 0 & & & & & & \\
\hline опора C & 0 & 2 & 1 & & & & & & \\
\hline Всего / Total & 126 & 515 & 108 & 4.1 & 0.86 & & & & \\
\hline
\end{tabular}

\section{Примечания / Notes:}

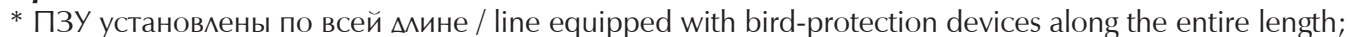

** ПЗУ установлены фррагментарно / line fragmentarily equipped with bird-protection devices on some of its stretches;

*** линия отк^ючена / line de-energized;

Тип ^ЭП: S - степная, F - полевая, R - придорожная, T - близ свалки, W - лесная / PL type: S - line in the steppe biotope, F line in the agricultural biotope, $\mathrm{R}$ - roadside line, $\mathrm{T}$ - line stretching along a landfill site, $\mathrm{W}$ - line stretching through the woodland; EB - electrocuted birds, ER - electrocuted raptors.

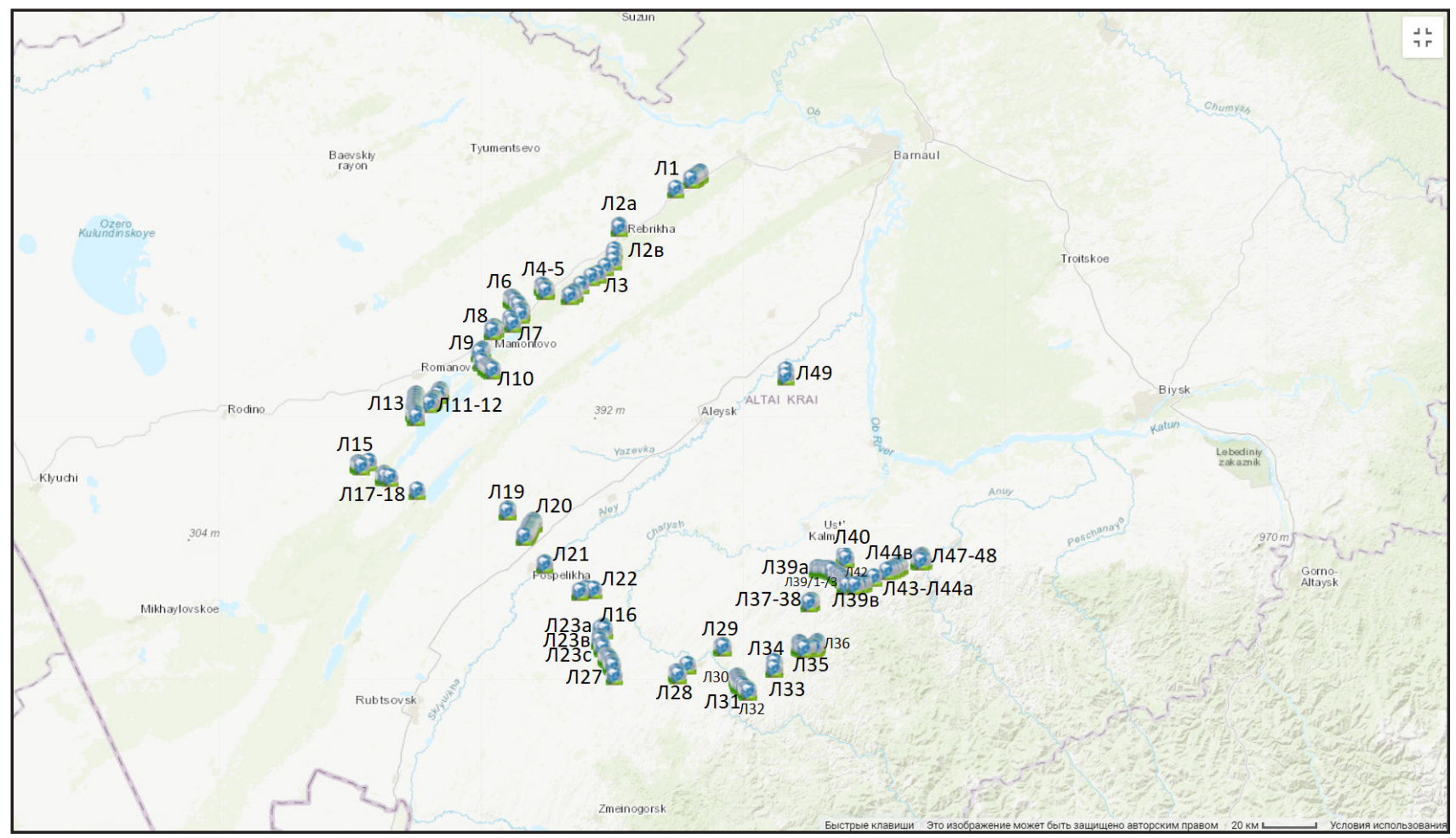

Рис. 2. Схематическое расположение прове-

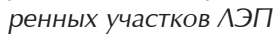
на карте.

Fig. 2. Location of examined power lines on a map of Altai Kray.
Ушерб от гибели орлов, чью точную виАовую приналмежность установить не уда^ось, бы^ рассчитан по самому низкому из нормативов Аля выявленных поА АЭП ви$\triangle$ ОВ орлов.

Аяя исчисления размера вреда, нанесённого видам, отнесённым к охотничьим, были взяты размеры таксы из Приложения 1 к Методике исчисления вреда, причинённого охотничьим ресурсам (Методика..., 2011), а значение пересчётного коэфрфициента «К» - из приложения 2 к той же Методике с теми же изменениями. Коэфрфициент «К» был установлен в размере $\mathrm{K}=3$ по параграфру 1,5 «Аействия (бездействия), по причине которых произошло уничтожение (гибель) охотничьих ресурсов умышленно surrounded by agricultural fields and pastures "field" type. In the current study there was also one line stretching through the woodland $(\wedge 2 \mathrm{a})$ and one running along a landfill $(\wedge 23 \mathrm{c})$, but we do not include them in this analysis. As well as de-energized lines ( $\wedge 9$ and $\wedge 40)$ and lines fully equipped with BPDs $(\wedge 16, \wedge 22, \wedge 44 a)$. The summary is present in table 3 . Steppe lines are responsible for death of half of all birds found $(50.1 \%)$ and of more than the half of all raptors $(58.1 \%)$, while the total length of steppe lines was the smallest (fig. 5). Steppe lines also caused death of 5 out of 10 endangered raptors - both a Long-Legged Buzzards, one a Peregrine, Pallid Harrier, and an eagle. Three other endangered raptors - Steppe Eagle, Greater Spotted Eagle, and another Peregrine died on the power lines 
или по халатности при осушествлении хозяйственной Аеятельности...».

Методика оценки Аавности гибели птиц подробно приведена в статье 2020 г. (Шнайдер и мр., 2020).

Во время проведения осмотра АЭП отмечались встречи живых хишных птиц вблизи миний, а также скоплений иных виАов птиц, используюших АЭП в качестве присаАы.

\section{Результаты и их обсуждение}

Суммарно на осмотренных миниях было обнаружено 515 трупов птиц 23 видов. Из них 108 трупов (21\%) приналлежали хишным птицам 11 видов, 10 трупов (1,94\%) - шести видам птиц, занесённым в Красную Книгу РФ (фрилин - 2 ос., сапсан - 2 ос., курганник Buteo rufinus - 2 ос., степной орёл - 1 ос., большой подорлик - 1 oc., степной мунь Circus macrourus - 1 ос. и орёл, чьи останки не удалось определить Ао вила Aquila sp./C. Clanga (рис. 3, табл. 1).

Средняя плотность погибших птиц на единицу Алины в обшем виде составила 4,1 ос./Км минии, а средняя плотность погибших хишных птиц - 0,86 ос./км. Но если искАючить Аинии, полностью оснашённые ПЗУ, и минии, обесточенные на момент осмотра, то есть $А$ остоверно безопасные мяя пернатых, то на оставшихся 91,8 км незашишённых ПО ^ЭП обшая плотность гибели составит 5,6 ос./км, а плотность гибели хишных птиц - 1,18 ос./км.

Обший ушерб, нанесённый пернатому населению, по результатам оценки, основанной на фрактическом числе найденных погибших птиц, состави^ 6125435 руб. (табл. 2). Основной вклаА в него внесли 10 особей видов, занесённых в КК РФ. На рис. 4 of the "field" type. And all three owls - 2 endangered Eagle Owls and 1 Great Grey Owl (Strix nebulosa) died on roadside lines.

By the density of dead raptors "steppe" type outnumbers the other two by 3.3 times (table 3). Thus, we again conclude that power lines stretching through open undisturbed habitats are the most dangerous for raptors and must be retrofitted in the first place.

In the present study, we observed a very high rate of scavenging on dead birds. In $63 \%$ of cases $(n=325)$ carcasses were completely consumed by scavengers and only feathers remain at the site of death under an electric pole. In $8 \%$ of cases $(n=41)$ carcasses were partially consumed and we found fragments of bodies on the sites of death. The whole carcasses on different stages of decomposition were found in 29\% of cases ( $n=149$ ) (fig. 6). Foxy (Vulpes vulpes) burrows and feces encountered near electric poles indicate that unsafe power lines are regularly visited by this mammal. Another effective consumer of dead birds in the region is a Black Kite (Milvus migrans), but in the second half of September, this species is already absent in Altai Kray since it is an early migrant departing in the first days of autumn. During the survey, we observed only one alive Black Kite near UPL $\wedge 13$, and one freshly deceased juvenile kite was found on UPL $\Lambda 31$.

All bird remains that were not completely consumed by scavengers $(n=190)$, i.e. at least a few bones and feathers remain on the site of death, undergone an estimation of time since death (TSD). TSD within 2 weeks was set very accurately based on the presence and the development of maggots and carrion-eating beetles. TSD within 2-10 weeks was estimated with an accuracy of two weeks. TSD of more than 12 weeks was estimated roughly with an
Рис. 3. А - Молодая самка сапсана (Falco peregrinus), погибшая на ПО АЭП А13. В Степной орёл (Aquila nipalensis), сеголеток, погибший на ПО АЭП 137. Фото Е. Шнайдер.

Fig. 3. A - Subadult female Peregrine (Falco peregrinus) died from electrocution on UPL 113. B - Juvenile Steppe Eagle (Aquila nipalensis), that died from electrocution on UPL 137. Photos by E. Shnayder.

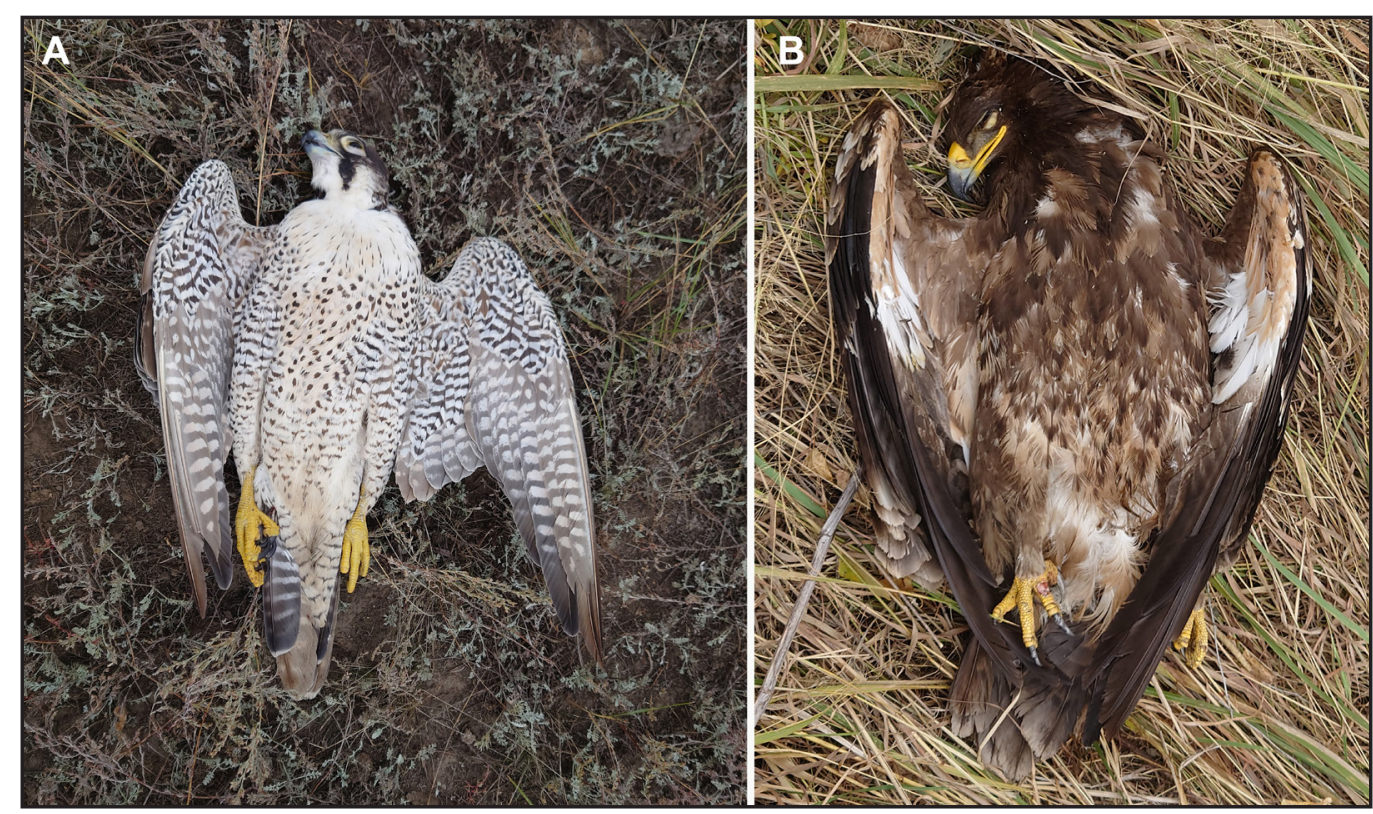


Табл. 2. Расчёт суммарного ушерба животному миру, исходя из числа найденных трупов птиц, погибших от поражения электротоком. Table 2. Calculation of damage caused to the ecosystem by power lines based on the number of birds found dead due to electrocution during the survey.

\begin{tabular}{|c|c|c|c|}
\hline Вимы/ Species & oc./ind. & Руб. за особь / Rub per ind. & $\begin{array}{l}\text { Итог с учётом КИ (К), руб. } \\
\text { Total (applying КИ or К), rub }\end{array}$ \\
\hline \multicolumn{4}{|c|}{$\begin{array}{l}\text { KК РФ }(K И=2,63) \\
\text { Red List of Russia }(K И=2.63)\end{array}$} \\
\hline Falco peregrinus & 2 & 600000 & 3156000 \\
\hline Bubo bubo & 2 & 50000 & 263000 \\
\hline Buteo rufinus & 2 & 10000 & 52600 \\
\hline Circus macrourus & 1 & 10000 & 26300 \\
\hline Aquila nipalensis & 1 & 50000 & 131500 \\
\hline Aquila clanga & 1 & 25000 & 65750 \\
\hline Aquila sp. & 1 & 25000 & 65750 \\
\hline \multicolumn{4}{|c|}{$\begin{array}{l}\text { He КК РФ }(К И=2,63) \\
\text { Not listed in the Red List of Russia }(K И=2.63)\end{array}$} \\
\hline Falconiformes & 30 & 5000 & 394500 \\
\hline Accipitriformes & 67 & 5000 & 881050 \\
\hline Strigiformes & 1 & 5000 & 13150 \\
\hline Piciformes & 1 & 3500 & 9205 \\
\hline Passeriformes & 401 & 1000 & 1054630 \\
\hline \multicolumn{4}{|l|}{$\begin{array}{l}\text { Охотничьи }(\mathrm{K}=3) \\
\text { Game species }(\mathrm{K}=3)\end{array}$} \\
\hline Lyrurus tetrix & 1 & 2000 & 6000 \\
\hline Columba livia & 3 & 600 & 5400 \\
\hline Streptopelia orientalis & 1 & 200 & 600 \\
\hline Итого / Total & 513 & & 6125435 \\
\hline
\end{tabular}

Примечания / Notes:

КИ - коэфффициент инфряяции, К - пересчётный коэфрфициент м^я охотничьих видов / КИ - inflation rate, К - соеfficient for game species.

представлены пропорции вклаха разных групп погибших птиц в обшее число найменных останков и в суммарный ушерб в рублёвом эквиваленте. Основная гибель птиц происходила на 91,8 км незашишён- accuracy of a few months. A summary is present in fig. 7.

The distribution of TSD along the time scale is fairly even. We found 20 and 25 birds with TSD (0-1) week and TSD (1-2) weeks re-
По сумме ущерба, руб

By the amount of damage in Rub

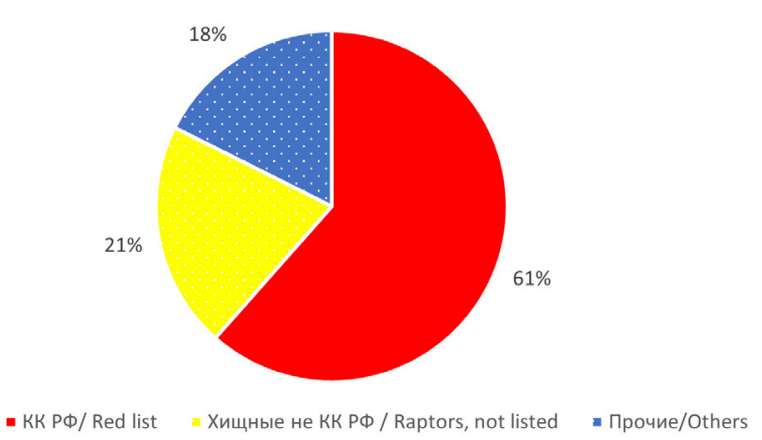

По числу особей

By the number of individuals

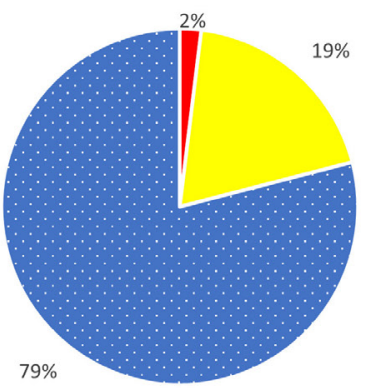

- КК РФ/Red list = Хищные не КК РФ / Raptors, not listed Прочие/Others

Рис. 4. ВклаА особей из разных охранных категорий в сумму обшего ушерба (слева) и в обшее число найденных погибших птиц (справа). Fig. 4. Contribution of individual birds with different protection rank into the amount of calculated damage (left) and in the total number of dead birds found (right). 
ных ПО ^ЭП. Можно оценить, что ушерб, приходяшийся на одну опору, при среднем количестве 17 опор в 1 км АЭП (Шнайдер и мр, 2020), составляет 3925 руб.

В предылуших работах (Карякин и мр., 2009, Шнайлер и мр., 2020) мы разделяли ПО ^ЭП по типам и показывали, что наибольшую опасность м^я хишных птиц преАставляют минии, идушие по открытым ненарушенным местообитаниям, а наименьшую - межпоселковые минии, тянушиеся вАОль автомобильных Аорог. В этой работе мы получили аналогичные результаты, поАелив линии на (1) «придорожные» - линии, илушие в пункты, (2) «степные» - ^инии, идушие по ненарушенным местообитаниям, и (3) «полевые» - минии, идушие через сельскохозяйственные поля, сенокосы и огороженные пастбиша. Также в Аанном исследовании был оАин участок, иАуший вАоль свалки (^23с) и один, тянушийся через бор (^2а).

Анализируя по отАельности три основных подтипа ПО АЭП - «степные», «полевые» и «придорожные кинии» (табл. 3), и не рассматривая одиночные опоры и $ы$ ве минии, имушие через бор и свалку, а также безопасные м^я птиц обесточенные минии (^9 и ^40) и минии, полностью оснашённые ПЗу (^16, ^22 и ^44а), получается следуюшая картина: на «степные» ПО ^инии приходит- spectively. In the next 3 weeks, the amount of non-consumed bird remains accumulated at the same rate -63 birds with TSD from 2 weeks to $4 \pm 1$ weeks (fig. 8 , blue graph). The next group of dead birds has TSD $8 \pm 2$ weeks $(n=46)$, and the last one TSD $12 \pm 2$ weeks $(n=27)$. And here the accumulation rate is slowing down compared with the previous 5 weeks. It could be due to the more intensive consumption of carcasses by Black Kites in summer before the onset of their autumn migration. A group of very old remains is formed by 9 individuals who died on power lines before the beginning of the breeding season of 2021, and they are not reflected in fig. 8 .

Limiting the sample set to raptors only and considering it in the same manner (fig. 8, orange graph) is revealing an obvious decrease in accumulation rate in September (TSD 0-2 weeks). We found only 6 recently deceased raptors out of 61 - two Common Buzzards, sad $q$ Peregrine, juv Black Kite, ad §̋ Goshawk (Accipiter gentilis), and juv Steppe Eagle. In all other TSD-groups, Black Kite is the dominant species with the majority of individuals (fig. 9). Buteo's mortality is peaking in July, Accipiter's in August. All owls died in June (TSD $=12 \pm 2$ ) that coincide with the terms of the postfledging period. Greater Spotted Eagle died at the beginning of August (the dead bird with $\mathrm{TSD}=6 \pm 2$ weeks was found on the $27^{\text {th }}$ of

Табл. 3. ВклаА АЭП различного типа расположения в гибель птиц.

Table 3. Contribution of power lines located in different habitats into bird mortality.

\begin{tabular}{|c|c|c|c|c|c|}
\hline $\begin{array}{l}\text { Тип } \\
\text { Tyре }\end{array}$ & $\begin{array}{l}\Delta \text { Ана, км/ } \\
\text { Length, km }\end{array}$ & $\begin{array}{r}\text { Погибшие } \\
\text { птишы, ос. } \\
\text { Electrocuted } \\
\text { birds (EB), ind. }\end{array}$ & $\begin{array}{r}\text { Погибшие } \\
\text { хишные птишы, } \\
\text { ос. } \\
\text { Electrocuted rap- } \\
\text { tors (ER), ind. }\end{array}$ & $\begin{array}{r}\text { Плотность } \\
\text { гибели птиш, } \\
\text { ос./1 км } \\
\text { Density of EB, } \\
\text { ind./ } 1 \text { km }\end{array}$ & $\begin{array}{r}\text { Плотность } \\
\text { гибели хишных } \\
\text { птиц, ос. /1 км } \\
\text { Density of ER, } \\
\text { ind./ } 1 \mathrm{~km}\end{array}$ \\
\hline $\begin{array}{l}\text { Степные }(n=9) \\
\text { Line in the steppe biotope }\end{array}$ & 26.4 & 240 & 61 & 9.1 & 2.31 \\
\hline $\begin{array}{l}\text { Полевые }(n=7) \\
\text { Line in the agricultural biotope }\end{array}$ & 28.5 & 87 & 20 & 3.1 & 0.7 \\
\hline $\begin{array}{l}\text { Прилорожные }(n=25) \\
\text { Roadside power lines }\end{array}$ & 34.1 & 152 & 24 & 4.5 & 0.7 \\
\hline $\begin{array}{l}\text { ^есная }(\wedge 2 \mathrm{~B}) \\
\text { Line stretching in the woodland }\end{array}$ & 1.5 & 0 & 0 & 0 & 0 \\
\hline $\begin{array}{l}\text { У свалки }(\wedge 23 c) \\
\text { Line stretching along a landfill site }\end{array}$ & 1.3 & 21 & 2 & 16 & 1.54 \\
\hline $\begin{array}{l}\text { Отк^ючённые }(\wedge 9, \wedge 40) \\
\text { De-energized lines }\end{array}$ & 11.2 & 2 & 0 & 0.2 & 0 \\
\hline $\begin{array}{l}\text { Полностью с ПЗУ }(\wedge 16, \wedge 22, \wedge 44 \text { a) } \\
\text { Lines fully equipped with BPD }\end{array}$ & 22.9 & 7 & 0 & 0.3 & 0 \\
\hline Всего / Total & 126 & 509 & 107 & & \\
\hline
\end{tabular}

Примечания / Notes:

ПЗУ - птицезашитные устройства / EB - electrocuted birds, ER - electrocuted raptors, BPD - bird protection devices. 
Рис. 5. Различия в уровне гибели птиц на полевых, степных и придорожных ПО АЭП

Fig. 5. Differences in the number of dead birds on "steppe", "field", and "roadside" types of unsafe power lines.

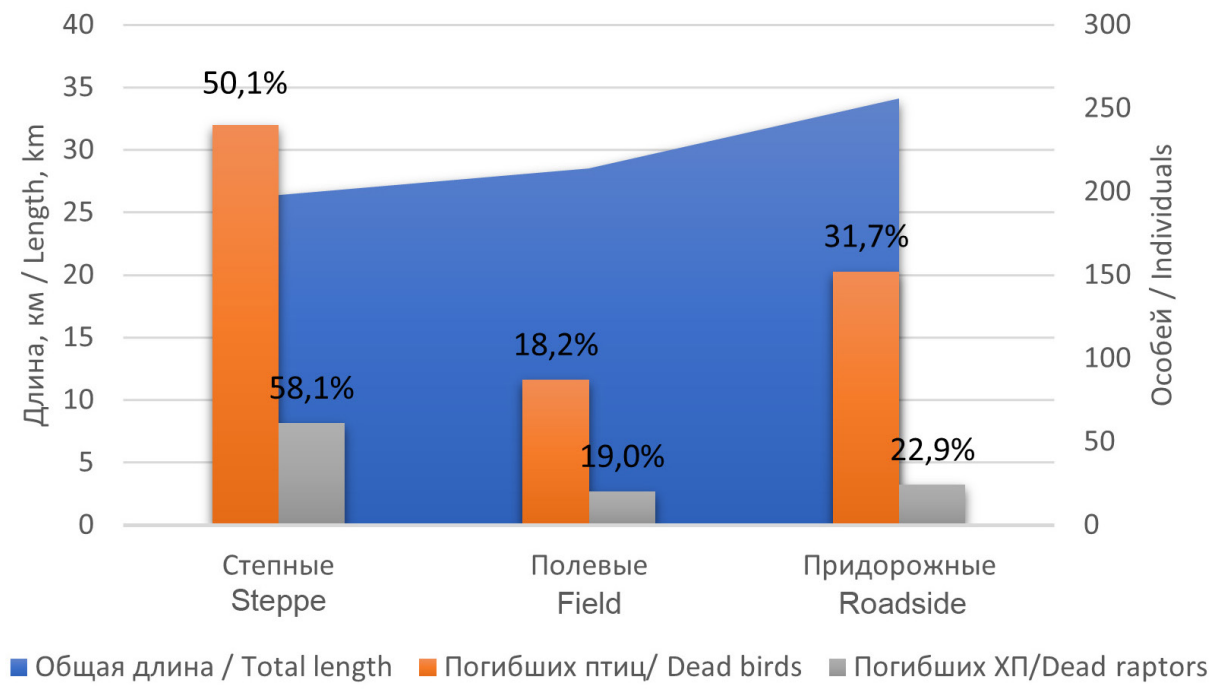

ся половина всех погибших птиц (50,1\%) и более половины погибших пернатых хишников (58,1\%), притом что суммарная миина «Полевых» ПО миний оказалась наименьшей из трёх подтипов (рис. 5). Также именно на степных ^иниях погибли 5 из 10 краснокнижных особей - оба курганника, сапсан, степной кунь и орёл, не определённый $\Delta$ О вида. Ешё три краснокнижных хишника - степной орёл, подорлик и сапсан погибки на «полевых» миниях. А все три ночных хишника - $\Delta$ ва фрилина и бородатая неясыть (Strix nebulosa) погибли на придорожных линиях в биотопах с оврагами.

По плотности гибели пернатых хишников «степные» минии превосходят «полевые» и «придорожные» в 3,3 раза (табл. 3). Таким образом, мы опять делаем выво $\Delta$, что ^ЭП, идушие через открытые ненарушенные биотопы, представляют максимальную опасность $\Delta$ я хишных птиц и Аолжны переоснашаться в первую очередь.

В нашем исследовании был отмечен очень высокий уровень утилизации погибших птиц наземными хишниками. При этом, под опорами остаются перьевые останки в виде компактной группы перьев, а тушки погибших птиц уносятся прочь, мибо под опорами остаются разорванные на фррагменты каркасы (рис. 6). Процент перьевых останков среди всех зафиксированных случаев гибели птиц на АЭП составил 63\% $(n=325)$ а фррагментированных останков - 8\% $(n=41)$. Шельные трупы, не подвергшиеся разбору со стороны хишников, наблюАались мишь в 29\% случаев $(n=149)$. Вблизи многих миний выявлены норы лис (Vulpes vulpes), мисий помёт по опорами, что свидетельствует о том, что ПО ^ЭП постоянно патрулируются этими
September), which is also coincided with the beginning of the post-fledging period. Steppe Eagle and Peregrines died in September - on autumn migration (fig. 9).

However, it must be remembered that in the present study we estimated TSD only for carcasses that were not completely consumed by scavengers (37\% from the total), while most of the bird carcasses (63\%) were completely removed from the place of death with only feathers remain as evidence of the case. It is also possible to estimate TSD by feather remains, but it will take much longer processing of collected material and is significantly less accurate, so we avoided it as an excessive measure.

However, the survey was accomplished with the utmost care - we recorded even fragments of skull, sole bones, and separate feathers sufficient to conclude that the bird who lost them died, not just molted. That means that a single feather we do not count as evidence of a mortal case, but a cluster of few primaries or rectrices, or a flap of skin with feathers we do. We believe this approach allows us to uncover most of the fatalities that occurred on the surveyed power lines starting from June. But earlier cases probably went unnoticed, because in the term of 3-4 warm months feather remains could completely decay through the action of bacteria and fungi, as well as rodents and invertebrates. The same is true for the birds that died in winter - their remains will not last over the summer. It also seems that we have a gap in the number of small and medium-sized passerine birds that died from electrocution since their small corpses can be consumed without any leftovers, and in fact, they are poorly represented among our samples (see below in the Species Composition chapter). 


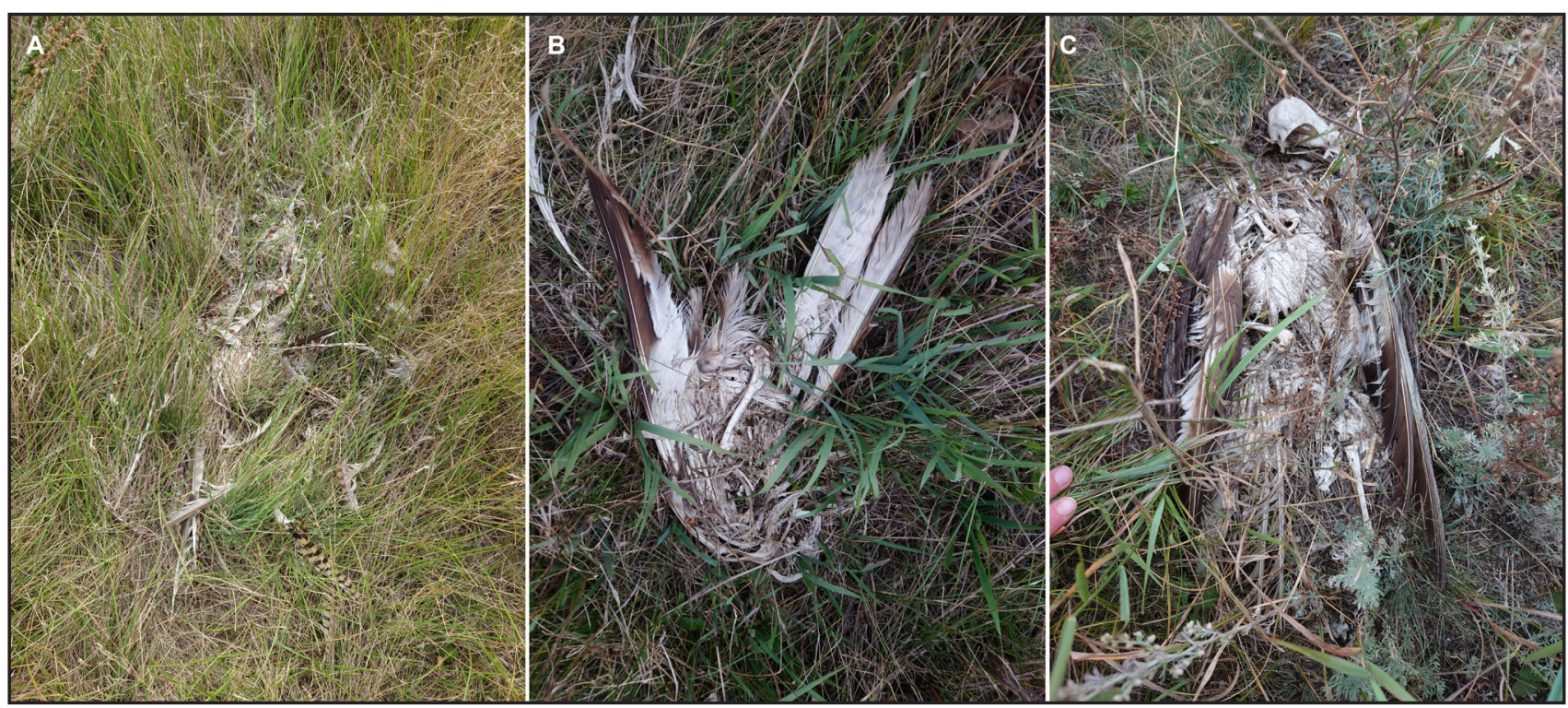

Рис. 6. А - Группа перьев, оставшаяся на месте гибели пустельги, после того как её тушку унёс хишник. В - Фрагментированные останки канюка после его утилизации паАальшиком на месте гибели. С - Погибший коршун (Milvus migrans), не подвергшийся утилизации паєальшиками. Фото Е. Шнайьер.

Fig. 6. A - Feathers remain on the site of death of a Common Kestrel after its body was taken away by a scavenger. B - Fragments of Common Buzzard's carcass left on the site of its death after its body was consumed by a scavenger. C - Carcass of a Black Kite (Milvus migrans) not being torn apart or taken away after death. Photos by E. Shnayder.

четвероногими хишниками. Аругой важный утилизатор пахали, чёрный коршун (Milvus migrans), отлетает в основной массе с мест гнездования в начале сентября. Во время Аанной проверки был встречен мишь оАин живой коршун близ ПО минии $\wedge 13$ и один погибший в течение суток на ПО минии $\wedge 31$.

$\Delta \wedge я$ всех останков, не подвергшихся утимизации, мибо подвергшихся, но от которых остались костные фррагменты $(n=190)$, был оценен срок гибели. Сроки гибели в пределах 2 нелель были установлены очень точно, по наличию и характеру роста кичинок мясных мух и жуков-трупоедов. Останки со сроком гибели от 2 оо 10 неАель были Аатированы с точностью $\Delta$ О $\Delta у х$ нелель. Возраст останков свыше 12 нелель Аатирован приблизительно, с точностью $\Delta$ о нескольких месяцев. Сводка по этому признаку представлена на рис. 7.
Speaking about birds that died on power lines in spring (April - May) and in October during migration, we propose a way to estimate their number based on the previous research. The study of 2009 showed that the rate of bird mortality in Altai Kray observed during the breeding season (5.15 ind./km, middle of May - end of July) was two times higher than in September (2.45 ind./km). However, the authors noted that in September 2009 "in 89.4\% of cases we found birds that died recently - within 5 days before we discover them", so they got a real "September rate". In our study of 2021, the survey conducted in September covered the period of 3-4 months according to our findings, and the rate of mortality $(5.6 \mathrm{ind} . / \mathrm{km})$ is close to the one observed in the summer of 2009. Let $x$ be the number of birds that died in September of 2021, then in June, July, and August the number of birds that died would be equal to $2 x$ per month. In total, from June since death.
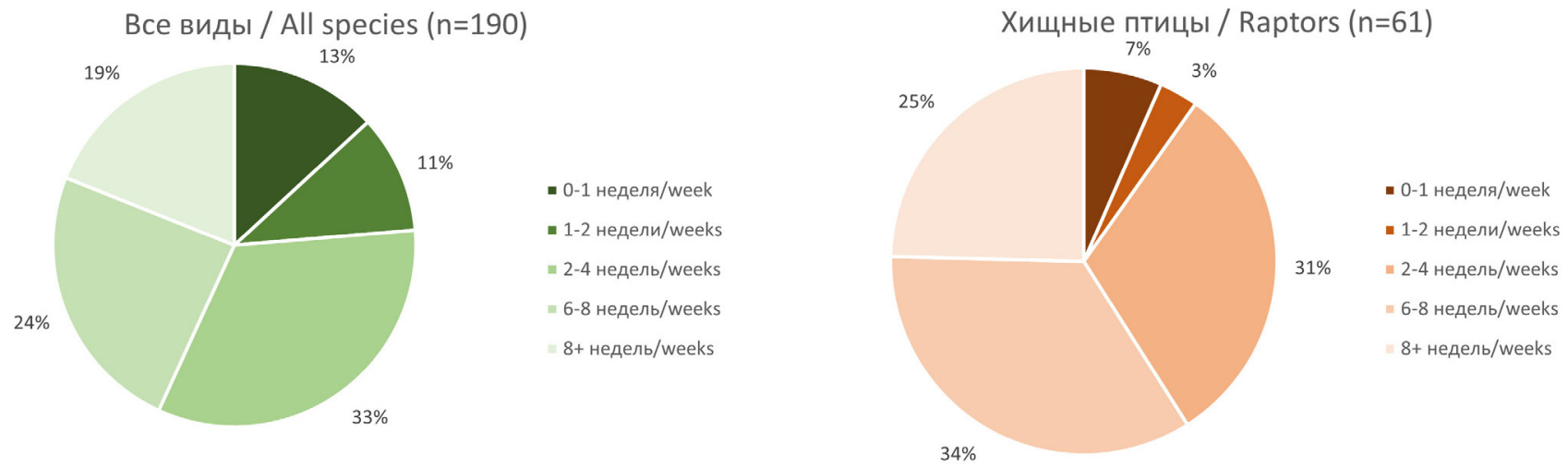


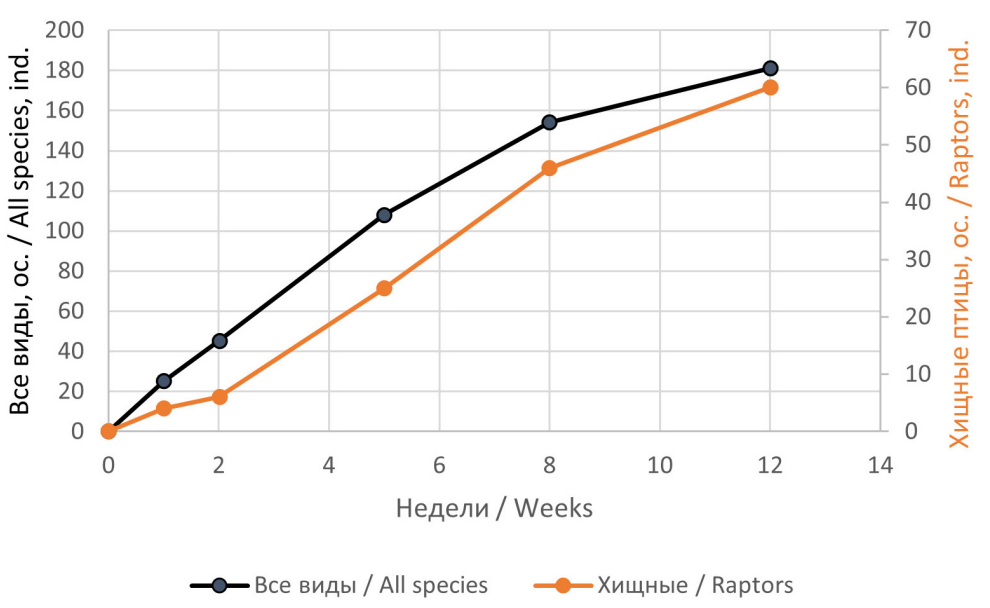

Распределение Аатированных останков по временной шкале $о$ остаточно равномерно. Было найлено 20 и 25 погибших птиц со сроком гибели $А$ о 1 недели и от 1 до 2 нелель соответственно. В последуюшие 3 нелели количество неутилизированных останков накапливается в таком же темпе - 63 погибших птицы, чья гибель была Аатирована сроком от 2 недель (точная Аатировка по мичинкам) $\Delta о$ 4 1 неде^я (примерная Аатировка с точностью $\Delta \mathrm{O} 2$ нелель) (рис. 8, синий график). Следуюшая группа останков Аатирована сроком $8 \pm 2$

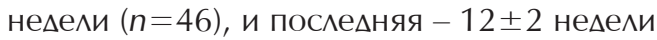
$(n=27)$. Тут уже наблюдается уменьшение скорости накопления неутилизированных останков по сравнению с предылушими пятью неделями. Это может быть связано с более интенсивной утилизацией погибших птиц коршунами $\Delta$ о начала их осеннего отлёта. Группу совсем старых останков

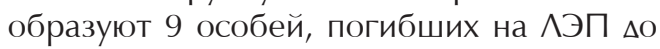
начала гнездового сезона 2021 года, они не приведены на графрике.

Аналогичное рассмотрение темпов накопления останков только хишных птиц под ^ЭП (рис. 8, оранжевый графрик) выявляет очевинное замедление их гибели на ^ЭП с начала сентября (останки, Аатированные сроком до 2 недель). Недавно погибшими были найдены мишь 6 хишников из 61: ва канюка, сапсан sad $q$, коршун juv, тетеревятник (Accipiter gentilis) ad $\hat{\sigma}$ и степной орё^ јuv. Во всех остальных возрастных группах среди хишников абсо^ютно АОминируют погибшие коршуны (рис. 9). Пик гибели канюков приходится на июль. Тетеревятников - на август. Все погибшие фрилины и бородатая неясыть

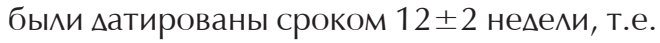
погибли в июне, что совпадает со сроком вылета молодых птиц. Гибель подорлика была датирована началом августа (обнару-
Рис. 8. Темп накопления неутилизированных останков поА ПОАЭП.

Fig. 8. The accumulation rate of non-consumed bird carcasses along UPLs.

to September it makes $7 x$ that is equal to 515 dead birds minus 9 very old bone remains. So, $x=72$ dead birds roughly. And in our model, it is the number of birds that died on the surveyed stretches of power lines during one month of migration. And during the breeding season, the monthly mortality of birds would be equal to 144 individuals. Applying this model to the whole period from April to October (3 months of migration and 4 breeding months), we will get 792 individuals per season.

Unfortunately, there is not enough data to build a model for winter mortality of birds on the same power lines. But for sure this mortality exists.

Extrapolation of our results to the whole territory of Altai Kray also faces obstacles due to the absence of publicly available data on the total length of unsafe power lines. In the open sources, we could find only (1) sum of the length of $0.4-10 \mathrm{kV}$ lines and (2) length of $35 \mathrm{kV}$ lines in the region in 2018, that makes $54,053.8 \mathrm{~km}$ and 4,743 km respectively (Decree of the Governor of Altai Kray...). But it is impossible to isolate from this number the actual length of bird-dangerous lines, i.e. lines of 6-35 kV on concrete poles, with bare wire, metal cross-arms, and pin insulators. But anyway, the estimate done by my colleagues 12 years ago $-2,880 \mathrm{~km}$ of unsafe power lines in the region today looks miserable. If at least 10\% of the length of 0.6-10 kV and $35 \mathrm{kV}(=5,880$ $\mathrm{km}$ ) would expose danger to birds, it will make incredible damage to the ecosystem. Namely, $5,880 \mathrm{~km}$ of UPLs is 64 times higher than the total length of UPLs we checked during the current work $(91.8 \mathrm{~km})$. And the potential damage could also be estimated as 64 times higher than the one observed in the present work, which makes it roughly 50,700 individuals or 603 million Rubles, excluding bids died in winter.

Fulfillment of obligations to retrofit dangerous power lines by power line owners

During the survey, we found several lines fully or partially equipped with bird-protection devices (BPDs), 7 lines in total (table 4). The total length of stretches with BPDs makes $27.94 \mathrm{~km}$. Three lines were fully and qualitatively retrofitted $-\wedge 16$ supplying a mobile tower (1.5 km, fully surveyed), $\wedge 22$ intervillage line (total length $-12.4 \mathrm{~km}, 5.4$ were surveyed), and $\wedge 44 \mathrm{a}$ intervillage line $(16 \mathrm{~km}$, fully 


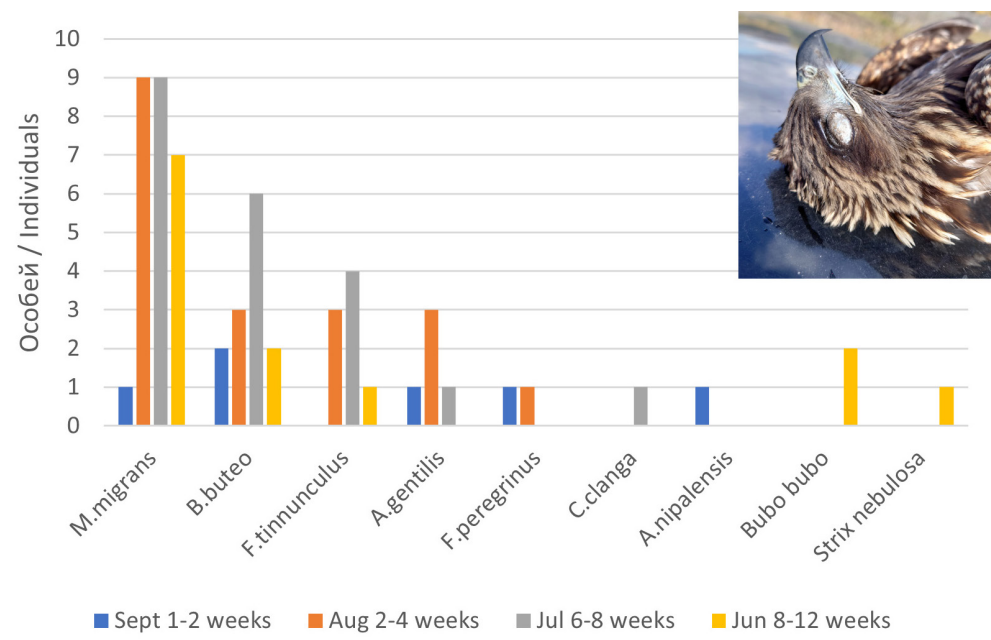

Рис. 9. Представленность разных виАов хишных птиц среди останков, Аатированных по срокам гибели на ПОАЭП.

Fig. 9. Species representation among raptor remains of different TSD-groups.

жен 27 сентября, срок гибели около 6 неиз гнезАа. Степной орёл и сапсаны погибми уже в сентябре, то есть во время миграции (рис. 9).

Необходимо напомнить, что Аатированы в этой работе были лишь неутилизированные останки и останки, которые утилизиАель) - также в срок выхода молодых птиц ровались прямо на месте гибели - всего 37\% от всех найденных. А 63\% выявленных останков птиц были утилизированы паАальшиками в стороне от места гибели, и фракт их гибели был установлен только по наличию пуха и перьев на месте гибели. Их Аатировка также возможна, но требует намного более м^ительной камера^ьной обработки собранного материала и сушественно менее точна.

При этом обследование территории по $\Delta$ ^ЭП велось очень тшательно - фриксировались маже случаи обнаружения фррагментов черепов или кластеров перьев, достоверно указываюших на гибель особи, а не на линьку. ЕАиничные перья не рассматрива^ись как свидетельство гибели птицы, но кластер из нескольких последовательных маховых или рулевых, мибо лоскут кожи с покровными перьями - рассматривались. Мы считаем, что при таком подходе нам удалось зафиксировать большинство случаев гибели птиц на АЭП, за искАючением, вероятно, представителей мелких воробьиных (Passeriformes), которые могут быть проглочены пахальшиками целиком (и действительно, мелкие воробьиные птицы практически не представлены в исследовании - см. далее). Наличие очень большого числа пухо-перьевых останков птиц среднего и крупного размерного класса по $\Delta$ опорами говорит о том, что паАальшики преимушественно ошипывают такую добычу на месте и уносят прочь уже компактную тушку, без маховых и руле- surveyed). Defective BPDs revealed during the survey are marked in the online database $\mathrm{e}^{20}$.

Besides exemplary lines with BPDs there were lines that possess BPDs only at the stretches close to the settlements and roads, while stretches hidden from view from the road were intact and continued killing birds ${ }^{23}$. The examples are $\wedge 31$ intervillage line ${ }^{24,25,26}$, ${ }^{27}$ with a total length of $7.52 \mathrm{~km}$ that got three stretches with BPDs near villages and roads of a total length of $2.72 \mathrm{~km}$; $\wedge 39 \mathrm{a}$ intervillage line ${ }^{28,29,30}$ only $0.75 \mathrm{~km}$ of a total $12.1 \mathrm{~km}$ length was equipped with BPDs from the village sides. This line was the cause of the death of an endangered Steppe Eagle! Furthermore, this line is stretching through the area reserved for the currently projected wildlife sanctuary "Northern face of Altai" (Karyakin et al., 2017) that is enlisted in the scheme of prospective protected areas of Altai Kray (Resolution..., 2013), and was urgently recommended for retrofitting with BPDs in 2009.

We also found BPDs on $\wedge 40$, but this line is de-energized. And a few BPDs on 119 , which supplied mobile tower in the past, but today it seems that the tower is connected to another UPL $(\wedge 19 / 2)$ without BPDs (in the table $1 \wedge 19$ and $\Lambda 19 / 2$ are described together, but in the database they are named differently) ${ }^{31}$.

Many lines surveyed in 2021 were also checked in 2009. As a result, in 2009 an agreement between "Siberian Environmental Center" $\mathrm{NGO}$ and power grid companies was concluded about joint activity on the environment protection in the zone of UPLs of Altai Kray, and a project for retrofitting of UPLs was prepared by the NGO. Repeated survey of $66.8 \mathrm{~km}$ of power lines (namely $\wedge 9, \wedge 11, \wedge 12, \wedge 13, \wedge 15, \wedge 31$, $\wedge 35, \wedge 37, \wedge 38, \wedge 39$ a and $b, \wedge 44 \mathrm{a}$ and $b, \wedge 47)$ in 2021 revealed that only $19.5 \mathrm{~km}$ were actually retrofitted, and only one power line $\wedge 44 \mathrm{a}$ undergoing regular maintaining and broken BPDs are replaced with new ones. But even that is not always (fig. 10).

Few lines built between 2010 and 2021 were carefully equipped with BPDs $-\wedge 16, \wedge 19$, and $\wedge 22$, or with self-supporting isolated wire - several short lines not mentioned in the text. But more commonly lines were built with violation of environmental protection legislation of Russia - ^8, ^20, ^34, ^48. And even more power lines continue to be operated without the slightest concern of their owners about the damage they doing to the ecosystem. It is notable that in the scheme and the program of development of the electric power industry in Altai Kray in 2019-2023 there is not a word about solving this problem, as if it does not exist (Decree of the Governor of Altai Kray..., 2018). 
вых перьев. И в большинстве случаев хоть какие-то следы утилизации трупа остаются близ опоры и выявляются при тшательном обследовании. Равномерное накопление останков птиц под ^ЭП также указывает на $А$ остаточно полный учёт объёма погибших птиц и его Аа^ьнейшее уточнение (вычисление коэфорициента утилизации, Карякин и мр., 2009; Шнайлер и др., 2020) не представляется возможным.

При проведении осмотра АЭП в сентябре, из учётов практически полностью выпадают месяцы весенней миграции - апрель и май, поскольку за 3-4 тёплых месяца перьевые останки птиц полностью утилизируются грызунами, беспозвоночными животными, грибами и бактериями. По той же причине почти не остаётся свиАетельств гибели птиц, убитых электротоком в зимний периол. Также неучтённой осталась гибель птиц в октябре, во время основного пролёта степных орлов.

По данным, полученным в 2009 г. на территории Алтайского края, уровень гибели птиц при проверке в гнездовой сезон (с середины мая по конец июля) составлял 5,15 ос./Км, а в сентябре - 2,45 ос./Км, то есть в Ава раза меньше. В 2021 г. уровень гибели птиц на незашишённых миниях, выявленный в сентябре (5,6 ос./км), был эквивалентен наблюдаемому в 2009 г. в гнездовой периол. Но, как указано в работе 2009 г., во время сентябрьской проверки «в 89,4\% случаев это были трупы птиц, погибших на АЭП в течение 5 нней $\Delta$ о момента их обнаружения», а в нашем обследовании осмотр Аостаточно полно охватывает периол гибе^и птиц с июня по конец сентября.

Аопустим, что во время гнезАового сезона на ^ЭП в А^тайском крае гибнет за единицу времени в $\Delta$ ва раза больше птиц, чем там же во время миграции, как это выявлено в работе 2009 г. Пусть за сентябрь погибает $(x)$ особей, тогАа за июнь, июль и август - по (2x) особей каждый месяц, что

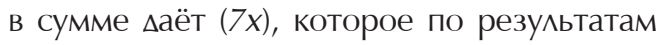
проверки составляет 515 особей, за вычетом останков 9 особей, чей возраст от момента гибели более полугода. Итого округлённо $x=72$ особи. Следовательно, в нашей модели, в месяцы миграции на осмотренных АЭП погибает по 72 особи, а в месяцы гнездового периола - по 144 особи. Применяя эти показатели к оставшимся неохваченными месяцам весенней миграции (апрель), началу гнездового сезона (май) и окончанию осенней миграции (октябрь), можно оценить обшую гибель птиц на осмотренных ^ЭП за сезон в 792 особи. Этот
The main power grid companies in Altai Kray today are "Federal grid company of unified energy system" PJSC, "Altaienergo" OJSC, "Grid company Altaikrayenergo" JSC, and "Barnaul grid company" LTD (p.3.1.3. Decree of the Governor of Altai Kray..., 2018). Management companies operating power lines surveyed in the present work are listed in table 5 (information taken from the public cadastral map $^{32}$ ).

\section{Analysis of pole types}

Surveyed power lines have two types of electric poles - intermediate and push brace. Push brace poles usually can be found at the ends of a line, at the beginning of a tap line, and at the points where a line changes its direction. The average ratio between push brace and intermediate poles is $1: 10$, which was calculated during the survey of ten random lines. But push brace poles are the ones that caused the death of $22 \%$ of all birds found electrocuted (fig. 11, inner circle), instead of the expected $9.1 \%$ as it would be in the case of equal frequency of casualties on push brace and intermediate poles. In other words, a push brace pole kills 2.9 times more birds than an intermediate pole.

The difference would be even more pronounced if we consider only raptors (fig.11, outer circle). Thirty-three percent of all raptors were found dead near push brace poles. The excess is 4.9 times compared with intermediate poles. And it is not rare to find 2 or 3 , or even 4 dead raptors near one push brace pole during the fieldwork (fig. 12).

An increased danger exposed by push brace poles is due to (1) linear disconnectors that are more commonly installed on this type of pole, and (2) geometry of wire associated with this type. Linear disconnectors (LD) are the most threatful elements of power lines (fig. 13a). LD has a shape of a wide metal frame that looks very promising for landing but has no insulation at all, and it locates closely to bare wire. Thus, it easily turns into a hot seat for a bird that dares to perch on it. Wires configuration on push brace poles is also likely to increase the chances for a casualty with birds. If a line changes its direction - the wire will make an angle; if there is an outcoming tap line, then another wire or two will complicate the geometry of wires (fig.13 a, b, c). In both cases, the distance between the wires is reduced that increases the risk of touching. The increased threat to birds from push brace poles has already been noted earlier (Matsyna, Zamazkin, 2010; Goroshko, 2011; Demeter et al., 2018, Shnayder et al., 2020).

That is why it is so important to install BPDs on push brace poles. Unfortunately, the current tendency is the opposite - in lines where 
показатель рассчитан мля осмотренных 91,8 км незашишённых ПО АЭП А^тайского края, проверенных в сентябре 2021 г. К сожалению, мля оценки гибели птиц в хо-

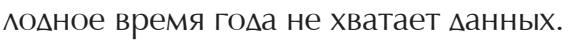

Попытке экстраполировать результат на территорию всего А^тайского края препятствует отсутствие открытых $а$ анных по обшей протяжённости птицеопасных ^ЭП в крае. В открытых источниках приведена млина миний электропередач напряжением 0,4-10 кВ и 35 кВ в А^тайском крае на 2018 г., которые составляли 54 053,8 км и 4743 км соответственно (Указ губернатора Алтайского края..., 2018). Но вычленить среди них минии, представляюшие опасность $А$ птиц, без осмотра на местности не представляется возможным, поскольку нигле не указан тип опор, марка проводов и траверс, тип установленных изоляторов. Тем не менее, оценка протяжённости ПО АЭП на А^тае в 2880 км, слеланная моими коммегами в 2009 году, сегодня выгляАит очень сильно заниженной. Если хотя бы 10\% от обшей протяжённости 0,4-35 кВ миний преАставляют угрозу Аля птиц, то это составит 5880 км, что в 64 раза боль-

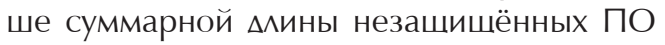
участков, проверенных в этом исследовании. Соответственно, число погибших птиц за сезон с апреля по октябрь на всей территории А^тайского края может быть оценено в 50700 особей. А обший ушерб животному миру в рублёвом эквиваленте при сохранении тех же пропорций по краснокнижным видам - в 603 млн. руб.

Выполнение собственниками миний обязанностей по оснашению миний ПЗу

При проведении проверок ПО АЭП были выявлены несколько миний, частично или полностью оснашённые ПЗУ, всего 7 миний (табл. 4). Обшая млина участков с ПЗу из проверенного километража составила 27,94 км. Три ^инии оказались полностью и качественно оснашены ПЗУ. Это миния $\bigwedge 16$ в Новичихинском районе из пос. Ве-

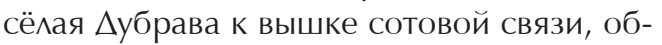
шей протяжённостью 1,5 км, осмотрена полностью; миния $\wedge 22$ в Поспелихинском районе из с. Николаевка в с. Калмыцкие мысы, обшей протяжённостью по карте как минимум 12,4 км, из которых 5,4 км были проинспектированы; а также миния $\wedge 44 а$ в Усть-Калманском районе из с. Огни в с. Михайловка Алиной 16 км, в которой представлены как бетонные опо-

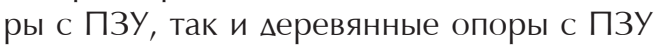
и без, осмотрена полностью. Выявленные intermediate poles are equipped with BPDs bush brace poles are often left unupgraded. Examples are lines $\wedge 16, \wedge 22, \wedge 44 a$, i.e. all lines that have been retrofitted by BPDs from start to end except for the push brace poles. This lack of attention to push brace poles may be due to the difficulty of installing BPDs on them, but it isn't an excuse to neglect the danger they pose. The good thing is birds really like BPDs, and our results show that the mortality rate for birds on unsafe poles in lines where all intermediate poles are equipped with protection is close to zero.

\section{Species composition of birds that died on power lines}

We observed 23 species of birds killed by power lines. The most common among them were Hooded Crows (Corvus cornix) and Rooks (Corvus frugilegus) - 304 individuals in total, 59\% of all dead birds. With less frequency, we found other synanthropic - magpies (Pica pica) (39 ind.), Jackdaws (Corvus monedula) (23 ind.), Starlings (Sturnus vulgaris) (16 ind.). The majority of electrocuted raptors were represented by 3 species - Black Kite (33 ind.), Common Buzzard (27 ind.), and Common Kestrel (30 ind.). We also found 7 dead Goshawks and 1 Great Grey Owl. Other raptors whose remains were found during the survey are enlisted in the Red List of Russia - Eagle Owl (2 ind.), Long-Legged Buzzard (2 ind.), Peregrine (2 ind.), Pallid Harrier (1 ind.), Greater Spotted Eagle (1 ind.), and Steppe Eagle (1 ind.). Bone fragments of one more eagle were not possible to ID up to species. Besides mentioned species, we also found remains of a Black Grouse (Tetrao tetrix), an Oriental Turtle Dove (Streptopelia orientalis), three Rock Pigeons (Columba livia), a Greater Spotted Woodpecker (Dendrocopus major), five Ravens (Corvus corax), and four small passerines of which only a Lesser Whitethroat (Curruca curruca) and a Skylark (Alauda arvensis) were possible to ID. And 11 more bone fragments remain unidentified.

The maximum species diversity of dead birds, 13 species, was observed on $\wedge 13$ line stretching through steppe biotope for $8.6 \mathrm{~km}$. This line also became an anti-leader by the density of dead raptors -4.42 ind. $/ \mathrm{km}$, with the share of raptors among other birds of $44.2 \%$.

On the field power lines $\wedge 35$ of $7.22 \mathrm{~km}$ length and $\Lambda 6$ of $4.5 \mathrm{~km}$ length, we observe the death of 10 and 9 species of birds respectively. Other lines with a length up to $2 \mathrm{~km}$ killed 5-7 species of birds. Lines less than $1 \mathrm{~km}$ in length killed 0-4 species. Lines from 1 to $2 \mathrm{~km}$ in length - 0-7 species of birds (table 1). 
Табл. 4. Аанные по миниям полностью или частично оборудованным ПЗу.

Table 4. Overview of power lines fully or partially equipped with bird protection devices.

\begin{tabular}{|c|c|c|c|c|c|}
\hline $\begin{array}{l}\text { Иньекс } \\
\text { Index }\end{array}$ & $\begin{array}{r}\text { Алина, км } \\
\text { Length, km } \\
\end{array}$ & $\begin{array}{l}\text { ПЗу, км } \\
\text { BPD, km } \\
\end{array}$ & $\begin{array}{r}\text { Брак ПЗУ, шт } \\
\text { Defective BPD, pcs } \\
\end{array}$ & $\begin{array}{r}\text { Плотность гибели птиц, ос./1 км } \\
\text { Density of EB, ind./ } 1 \text { km }\end{array}$ & $\begin{array}{r}\text { Район } \\
\text { District }\end{array}$ \\
\hline$\wedge 16$ & 1.5 & 1.5 & 4 & 0 & $\begin{array}{l}\text { Новичихинский } \\
\text { Novichikhinskiy }\end{array}$ \\
\hline$\wedge 19$ & 0.56 & 0.17 & 0 & 5.4 & $\begin{array}{l}\text { Поспелихинский } \\
\text { Pospelikhinskiy }\end{array}$ \\
\hline$\wedge 22$ & 5.4 & 5.4 & 0 & 0 & $\begin{array}{l}\text { Поспелихинский } \\
\text { Pospelikhinskiy }\end{array}$ \\
\hline$\wedge 31$ & 7.52 & 2.72 & 5 & 2.8 & $\begin{array}{l}\text { Красношёковский } \\
\text { Krasnoschyokovskiy }\end{array}$ \\
\hline$\wedge 39 a$ & 12.1 & 0.75 & 2 & 1.8 & $\begin{array}{r}\text { Усть-Камманский } \\
\text { Ust-Kalmanskiy }\end{array}$ \\
\hline$\wedge 40$ & 9.5 & 1.4 & 0 & 0 & $\begin{array}{r}\text { Усть-Камманский } \\
\text { Ust-Kalmanskiy }\end{array}$ \\
\hline$\wedge 44 a$ & 16 & 16 & 10 & 0.4 & $\begin{array}{r}\text { Усть-Камманский } \\
\text { Ust-Kalmanskiy }\end{array}$ \\
\hline Всего / Total & 52.6 & 27.94 & 21 & & \\
\hline
\end{tabular}

случаи дефректов в установленных ПЗУ отмечены в таблице 4 и внесены в раздел «ООПТ и антропогенные угрозы» ${ }^{20}$ вебГИС «Фаунистика».

ОАнако помимо полностью оснашённых ^иний, были выявлены кинии, на которых ПЗУ были установлены только в непосредственной близости от населённых пунктов и автомобильных Аорог, а участки ^ЭП, которые с трассы не просматриваются, были проигнорированы полностью ${ }^{23}$. Такими примерами яв^яются ^инии $\wedge 31$ в Красношёковском районе из с. Маралиха в с. Куйбышево $24,25,26,27$ обшей протяжённостью 7,52 км, из которых ПЗУ имеют три участка вблизи автомобильных Аорог, обшей Алиной 2,72 км; а также линия $\bigwedge 39$ а в Усть-Калминском районе, идушая из с. Новокамманка в с. Огни ${ }^{28,29,30}$, обшей $А$ иной 12,1 км, из которых мишь 0,75 км оснашены ПЗУ несколько опор со стороны Новокалманки, и чуть большее число опор со стороны с. Огни. Аанная миния стала причиной гибели краснокнижного степного орла! При этом эта АЭП тянется через проектируемый заказник «Северный фрас А^тая» (Карякин и мр., 2017), вк^ючённый в схему перспективных ООПТ А^тайского края (Постановление..., 2013) и была рекоменАована к оснашению ПЗУ ешё в 2009 г.

Ешё короткий участок с ПЗУ был выявлен на ^инии $\wedge 40$ со 143 по 170 опоры посреди

\section{Live raptors accounting on power lines}

During the survey, we recorded observations of live raptors in the close vicinity of power lines under study. The results showed in table 6 .

In total, we counted 45 birds of prey. Of these, 31 individuals (68.9\%) do not interact with power infrastructure at all, preferring natural perches like trees, rocks, haystacks, or either flying. Out of the remaining 14 raptors, two $(4.4 \%)$ were observed perching on wire and insulators of the de-energized power line (Common Kestrel and Eastern Imperial Eagle); 7 raptors (15.5\%) used safe wooden poles as a perch (Eastern Imperial Eagles, White-Tailed Eagles, a Common Buzzard, a Common Kestrel, and a Sparrowhawk (Accipiter nisus); 4 more kestrels (8.9\%) were observed perching on a wire of UPLs with concrete poles; and only one bird (2.2\%) - a Common Kestrel used an insulator of UPL.

Obviously, large raptors are avoiding live medium voltage power lines with concrete poles. They knowingly choose non-numerous wooden poles against the background of an abundance of concrete poles for perching and do not land on a free concrete pole if the place on the wooden is occupied (fig. 14 a, b). Our colleagues from the Orenburg region (Barbazyak, Petrischev, 2011) also noted the same stereotype - in the area with UPLs with concrete poles and metal cross-arms and safe power lines with wooden poles with-
23 http://youtu.be/X9npMtK9buA

24 http://oopt.wildlifemonitoring.ru/?lang=ru\#object/o_id $=197608$

25 http://oopt.wildlifemonitoring.ru/?lang=ru\#object/o_id $=197611$

26 http://oopt.wildlifemonitoring.ru/?lang=ru\#object/o_id $=197619$
27 http://oopt.wildlifemonitoring.ru/?lang=ru\#object/o id $=197622$

${ }_{28}$ http://oopt.wildlifemonitoring.ru/?lang=ru\#object/o_id $=197658$

29 http://oopt.wildlifemonitoring.ru/?lang=ru\# object/o ${ }^{-}$id $=197670$

30 http://oopt.wildlifemonitoring.ru/?lang=ru\#object/o_id $=197672$ 
сельскохозяйственных угодий, которая на момент проверки была отключена и неизвестно, будет ли использоваться снова. А также несколько опор с ПЗУ были выявлены в с. Клепчиха, на линии ^19, ведушей к сотовой вышке. ОАнако к этой же самой вышке с $А$ ругой стороны по ххоит ешё одна птицеопасная миния без ПЗУ $\left(\wedge 19 / 2^{31}\right)$, которая эту вышку очевидно и питает, поскольку под ней найдены трупы птиц. По состоянию трансорорматоров около вышки, создаётся впечатление, что безопасная миния, оснашённая ПЗУ, простаивает, а питание к вышке подаётся через новую ПО ^ЭП без птицезашиты. В таблице 1 минии 19 и 19/2 обсчитаны как единая, но в базе Аанных они имеют раздельную нумерацию.

Большая протяжённость ПО АЭП, осмотренных в 2021 году, уже была проверена в 2009 г. ТогАа по результатам проверки к собственникам миний, МРСК Сибири и фрилиалам ОАО «А^тайэнерго», было направлено предложение о сотрудничестве, которое привело к подписанию соглашения о совместной Аеятельности межАу МРСК Сибири и Сибэкоцентром. Была подготовлена программа по оснашению АЭП ПЗУ. Повторная проверка 66,8 км миний в 2021 году (а именно минии ^9, ^11, ^12, ^13, $\wedge 15, \wedge 31, \wedge 35, \wedge 37, \wedge 38, \wedge 39$ а и b, ^44 а и b, ^47) показала, что ПЗу были установлены лишь на 19,5 км линий, а регулярное техобслуживание с заменой поломанных элементов на новые качественно ведётся лишь на минии $\wedge 44$ a. $\Delta$ а и то не всегла (рис. 10).

Некоторые новые кинии, сооружённые в крае с 2009 г., были оборудованы ПЗУ - линии $\bigwedge 16$ и ^19 к сотовым вышкам и межпоселковая $\wedge 22$, мибо проводами типа СИП-3, например, ^иния к пос. Красный Май от трассы К-19, минии к ряду сотовых вышек, новых туристических баз и частных хозяйств, которые мы не осматривали, но отмечали в ходе работы. ОАнако целый ряд Аругих линий был возвелён без соблюдения природоохранного законодательства - в качестве примеров можно привести минии ^8, ^20, ^34, ^48, и ешё большее число линий продолжает эксплуатироваться без обеспечения безопасности объектам животного мира. Интересно, что в схеме и программе развития электроэнергетики А^тайского края〉 на 2019-2023 годы вопрос о решении Аанной проблемы Ааже не поднимается (Указ губернатора А^тайского края..., 2018).

Сейчас на территории Алтайского края основными эмектросетевыми компания-

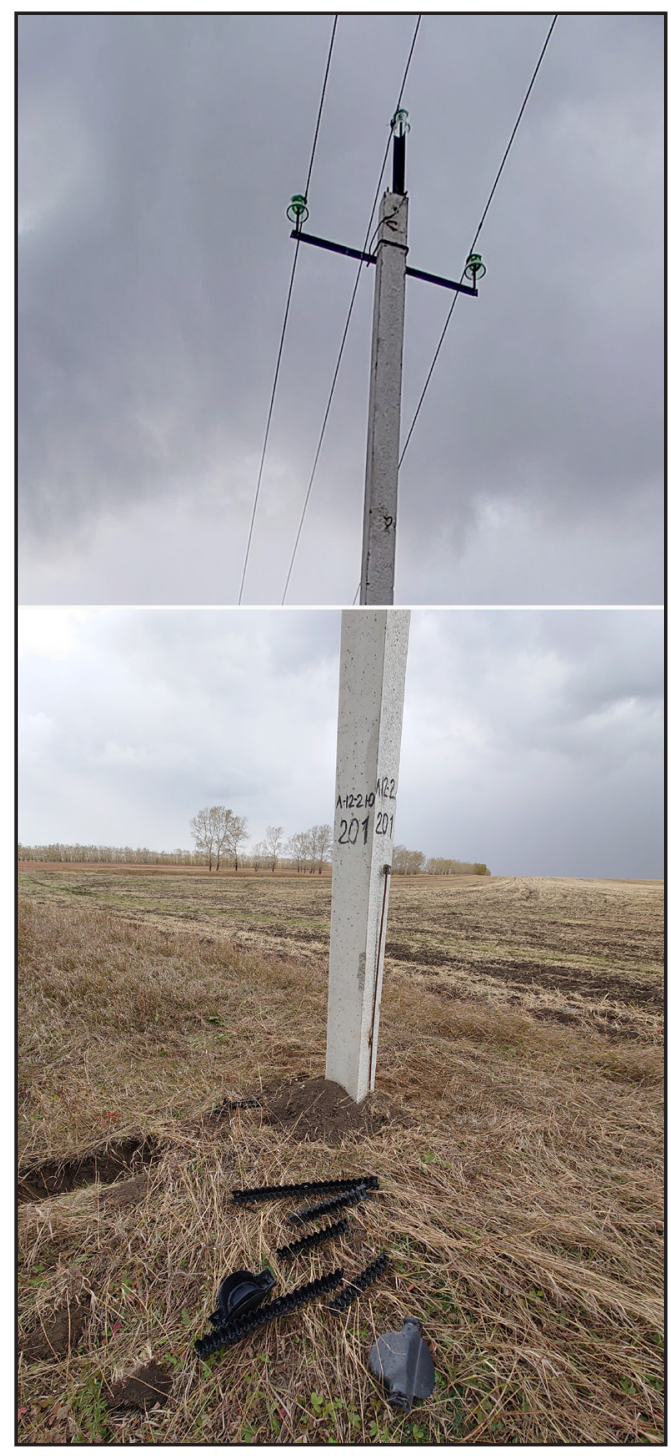

Рис. 10. Аиния $144 а$ - произведена замена опоры без восстановления на ней ПЗу.

Fig. 10. Replacement of the electric pole on the power line 144 a without restoring bird protection.

out cross-arms Steppe Eagles prefer the latter for perching. But this stereotype does not spread on de-energized power lines where eagles make no difference between wooden and concrete poles (I.V. Karyakin, personal communication). In our study, the only eagle perching on power infrastructure was also observed on the de-energized line (fig. $14 \mathrm{c}$ ). As we noted before (Shnayder et al., 2020), birds of prey evolve a pattern of avoiding unsafe power lines supported by (natural) selection.

In the same article of 2020 (Shnayder et al., 2020) we discussed a possible mechanism of evolving such a pattern when the pole type act

31 http://oopt.wildlifemonitoring.ru/?lang=ru\#object/o_id=197711 
ми яв^яются: фрилиал ПАО «Федеральная сетевая компания единой энергетической системы» - «Западно-сибирское предприятие магистральных электрических сетей», ОАО «А^тайэнерго»; АО «Сетевая компания А^тайкрайэнерго»; ООО «Барнаульская сетевая компания» (п. 3.1.3. Указ губернатора А^тайского края..., 2018). Распределение осмотренных в 2021 г. миний по собственникам представлено в таблице 5 (инорормация взята из публичной кахастровой карты $\left.{ }^{32}\right)$. as a factor of selection - only those who avoid dangerous poles survive and reproduce. Here we want to propose an additional hypothesis birds (raptors) can sense live lines. It was proven that birds can see the direction and sense the strength of the earth's magnetic field. The mechanism of the reception was uncovered recently, and it is associated with pigment in the bird's eye and magnetically sensitive cells in the beak (Wiltschko\&Wiltschko, 2019). It is possible that birds can simply percept the magnetic field of live lines and consider its ab-

Табл. 5. Сведения об осмотренных АЭП из каАастровой карты.

Table 5. Data on surveyed power lines from the publicly available cadastral map.

\begin{tabular}{|c|c|}
\hline $\begin{array}{l}\text { Иньекс } \\
\text { Index }\end{array}$ & $\begin{array}{l}\text { Название в каАастре } \\
\text { Name in cadaster }\end{array}$ \\
\hline 1 & 2 \\
\hline$\wedge 1$ & $\mathrm{~B} \wedge 10$ кВ ^-53-1 \\
\hline$\wedge 2 \mathrm{a}$ & $\begin{array}{l}\text { Электросетевой комплекс № Ц-3 } \\
\text { Ребрихинский }\end{array}$ \\
\hline$\wedge 2 \mathrm{~B}$ & $\begin{array}{l}\text { В камастре не отмечена } \\
\text { Not listed in the cadaster }\end{array}$ \\
\hline$\wedge 3$ & $\begin{array}{l}\text { Э^ектросетевой комплекс № Ш-3 } \\
\text { Ребрихинский }\end{array}$ \\
\hline$\wedge 4$ & Э^ектросетевой комплекс № C-10 \\
\hline$\wedge 5$ & Э^ектросетевой комплекс № C-10 \\
\hline$\wedge 6$ & Э^ектросетевой комплекс № C-10 \\
\hline$\wedge 7$ & Э^ектросетевой комплекс № C-10 \\
\hline$\wedge 8$ & $\begin{array}{l}\text { В каластре не отмечена } \\
\text { Not listed in the cadaster }\end{array}$ \\
\hline$\wedge 9$ & Э^ектросетевой комплекс №C-10 \\
\hline$\wedge 10$ & Э^ектросетевой комп^екс № C-10 \\
\hline$\wedge 11$ & Э^ектросетевой комплекс № C-9 \\
\hline$\wedge 12$ & Э^ектросетевой комп^екс №C-9 \\
\hline$\wedge 13$ & Э^ектросетевой комплекс № C-9 \\
\hline$\wedge 15$ & $\mathrm{~B} \wedge 10 \kappa \mathrm{B} \wedge-36-2$ \\
\hline
\end{tabular}

^16 В каластре не отмечена Not listed in the cadaster

$\wedge 17 \quad$ В^ 10 кВ ^-36-4

$\wedge 18 \quad$ В^ $10 \kappa \mathrm{\kappa} \wedge-36-2$

$\wedge 19 \quad$ В^ $10 \kappa$ кВ $\wedge-12-6$

^19 Магистральная киния, участок LWFL2RUALT100360

$\wedge 20 \quad$ В^ 10 кВ $\wedge-12-6$

$\wedge 21 \quad$ В^ 10 кВ ^-23-2

$\wedge 22$ В^ 10 кВ ^-41-2

$\wedge 23 a \quad$ В^ 10 кВ ^-17-3
Район / District

3

Пав^овский / Pavlovskiy

Ребрихинский / Rebrihinskiy

Ребрихинский / Rebrihinskiy

Ребрихинский / Rebrihinskiy

Мамонтовский / Mamontovskiy Мамонтовский / Mamontovskiy Мамонтовский / Mamontovskiy Мамонтовский / Mamontovskiy Мамонтовский / Mamontovskiy

Мамонтовский / Mamontovskiy Мамонтовский / Mamontovskiy Романовский / Romanovskiy Романовский / Romanovskiy Романовский / Romanovskiy Волчихинский / Volchihinskiy

Курьинский / Kuryinskiy

Новичихинский Novichihinskiy

Новичихинский Novichihinskiy

Поспекихинский Pospelihinskiy

Поспелихинский Pospelihinskiy

Поспелихинский / Pospelihinskiy

Поспелихинский / Pospelihinskiy

Поспелихинский / Pospelihinskiy Влахелец / Owner 4 Не указан / Not indicated OAO "MPCК Сибири" / OJSC "MRSK Siberian"

В каластре не отмечена / Not listed in the cadaster

OAO "MPCК Сибири" / OJSC "MRSK Siberian"

OAO "МРСК Сибири" / OJSC "MRSK Siberian" OAO "MРСК Сибири" / OJSC "MRSK Siberian" OAO "MРСК Сибири" / OJSC "MRSK Siberian" OAO "MPCК Сибири" / OJSC "MRSK Siberian" В каластре не отмечена / Not listed in the cadaster

OAO "MPCК Сибири" / OJSC "MRSK Siberian" OAO "МРСК Сибири" / OJSC "MRSK Siberian" OAO "MPCК Сибири" / OJSC "MRSK Siberian" OAO "МРСК Сибири" / OJSC "MRSK Siberian"

OAO "МРСК Сибири" / OJSC "MRSK Siberian" Новичихинский электросетевой комплекс № 3-8, на территории Волчихинского района Novichiha's Power Grid Complex № 3-8

В каластре не отмечена / Not listed in the cadaster

Новичихинский электросетевой комплекс № 3-8, на территории Новичихинского района Novichiha's Power Grid Complex № 3-8

Новичихинский электросетевой комплекс № 3-8, на территории Новичихинского района Novichiha's Power Grid Complex № 3-8

Поспелихинский электросетевой комплекс № 3-9 Pospeliha's Power Grid Complex № 3-9

OAO "ВымпелКом" / OJSC "Vimpelcom"

Поспелихинский электросетевой комплекс № 3-9 Pospeliha's Power Grid Complex № 3-9

Поспелихинский электросетевой комплекс № 3-9 Pospeliha's Power Grid Complex № 3-9

Поспелихинский электросетевой комплекс № 3-9 Pospeliha's Power Grid Complex № 3-9

Курьинский / Kuryinskiy Курьнский электросетевой комплекс фрилиала ОАО «Алтайэнерго» Южные электрические сети / OJSC "Altaienergo"

32 http://pkk.rosreestr.ru 
Табл. 5. Сведения об осмотренных АЭП из каАастровой карты (Продолжение).

Table 5. Data on surveyed power lines from the publicly available cadastral map (Continuation).

\begin{tabular}{|c|c|c|c|}
\hline 1 & 2 & 3 & 4 \\
\hline$\wedge 23 b$ & $\mathrm{~B} \wedge 10 \kappa \mathrm{B} \wedge-17-3$ & Курьинский / Kuryinskiy & $\begin{array}{l}\text { Курьинский электросетевой комплекс фрилиала OAO «Аитай- } \\
\text { энерго» Южные электрические сети / OJSC "Altaienergo" }\end{array}$ \\
\hline$\wedge 23 \mathrm{C}$ & $\mathrm{B} \wedge 10$ кВ $\wedge-17-3$ & Курьинский / Kuryinskiy & $\begin{array}{l}\text { Курьинский электросетевой комплекс фрилиала OAO «Аитай- } \\
\text { энерго» Южные электрические сети / OJSC "Altaienergo" }\end{array}$ \\
\hline$\wedge 27$ & $\mathrm{~B} \wedge 10$ кВ ^-17-3 & Курьинский / Kuryinskiy & $\begin{array}{l}\text { Курьинский электросетевой комплекс фрилиала OAO «Аитай- } \\
\text { энерго» Южные электрические сети / OJSC "Altaienergo" }\end{array}$ \\
\hline$\wedge 28$ & $\mathrm{~B} \wedge 10$ кВ ^-46-2 & $\begin{array}{l}\text { Красношёковский } \\
\text { Krasnoschyokovskiy }\end{array}$ & $\begin{array}{r}\text { Красношековский электросетевой комплекс фрилиала ОАО } \\
\text { «Алтайэнерго» Южные электрические сети } \\
\text { OJSC "Altaienergo" }\end{array}$ \\
\hline$\wedge 29$ & $\begin{array}{l}\text { В кацастре не отмечена } \\
\text { Not listed in the cadaster }\end{array}$ & $\begin{array}{l}\text { Красношёковский } \\
\text { Krasnoschyokovskiy }\end{array}$ & В каластре не отмечена / Not listed in the cadaster \\
\hline$\wedge 30$ & $\mathrm{~B} \wedge 10$ кВ $\wedge-55-4$ & $\begin{array}{l}\text { Красношёковский } \\
\text { Krasnoschyokovskiy }\end{array}$ & $\begin{array}{r}\text { Красношековский электросетевой комплекс фрилиала ОАО } \\
\text { «Аитайэнерго» Южные электрические сети } \\
\text { OJSC “Altaienergo" }\end{array}$ \\
\hline$\wedge 31$ & $\mathrm{~B} \wedge 10$ кВ ^-55-4 & $\begin{array}{l}\text { Красношёковский } \\
\text { Krasnoschyokovskiy }\end{array}$ & $\begin{array}{r}\text { Красношековский электросетевой комплекс фрилиала ОАО } \\
\text { «Алтайэнерго» Южные электрические сети } \\
\text { OJSC "Altaienergo" }\end{array}$ \\
\hline$\wedge 32$ & В^ 10 кВ ^-55-4 & $\begin{array}{l}\text { Красношёковский } \\
\text { Krasnoschyokovskiy }\end{array}$ & $\begin{array}{r}\text { Красношековский электросетевой комплекс фрилиала ОАО } \\
\text { «Алтайэнерго» Южные электрические сети } \\
\text { OJSC “Altaienergo" }\end{array}$ \\
\hline$\wedge 33$ & $\begin{array}{l}\text { В камастре не отмечена } \\
\text { Not listed in the cadaster }\end{array}$ & $\begin{array}{l}\text { Красношёковский } \\
\text { Krasnoschyokovskiy }\end{array}$ & В каластре не отмечена / Not listed in the cadaster \\
\hline$\wedge 34$ & $\begin{array}{l}\text { В кацастре не отмечена } \\
\text { Not listed in the cadaster }\end{array}$ & $\begin{array}{l}\text { Красношёковский } \\
\text { Krasnoschyokovskiy }\end{array}$ & В кацастре не отмечена / Not listed in the cadaster \\
\hline$\wedge 35$ & $\mathrm{~B} \wedge 10$ кВ ^-13-11 & Чарышский / Charyshskiy & $\begin{array}{r}\text { Э^ектросетевой комплекс № ЮС-8 «Чарышский» фрилиала } \\
\text { OAО «Аитайэнерго» Южные электрические сети } \\
\text { OJSC “Altaienergo" }\end{array}$ \\
\hline$\wedge 36$ & $\mathrm{~B} \wedge 10$ кВ ^-13-11 & Чарышский / Charyshskiy & $\begin{array}{r}\text { Электросетевой комплекс № ЮС-8 «Чарышский» фрилиала } \\
\text { ОАО «Алтайэнерго» Южные электрические сети } \\
\text { OJSC “Altaienergo" }\end{array}$ \\
\hline$\wedge 37$ & $\begin{array}{l}\text { В кахастре не отмечена } \\
\text { Not listed in the cadaster }\end{array}$ & $\begin{array}{l}\text { Усть-Калманский } \\
\text { Ust-Kalmanskiy }\end{array}$ & В кадастре не отмечена / Not listed in the cadaster \\
\hline$\wedge 38$ & $\begin{array}{l}\text { В кахастре не отмечена } \\
\text { Not listed in the cadaster }\end{array}$ & $\begin{array}{r}\text { Усть-Калманский } \\
\text { Ust-Kalmanskiy }\end{array}$ & В камастре не отмечена / Not listed in the cadaster \\
\hline$\wedge 39 \mathrm{a}$ & $\mathrm{B} \wedge 10$ кВ ^-12-8 & $\begin{array}{r}\text { Усть-Калманский } \\
\text { Ust-Kalmanskiy }\end{array}$ & $\begin{array}{r}\text { Электросетевой комплекс № Ю-7 «Усть-Калманский» } \\
\text { фрилиала ОАО «Алтайэнерго» Южные электрические сети } \\
\text { OJSC “Altaienergo" }\end{array}$ \\
\hline$\wedge 39 b$ & $\mathrm{~B} \wedge 10$ кВ ^-12-8 & $\begin{array}{r}\text { Усть-Калманский } \\
\text { Ust-Kalmanskiy }\end{array}$ & $\begin{array}{r}\text { Э^ектросетевой комплекс № Ю-7 «УСть-Камманский» } \\
\text { фрилиала ОАО «Алтайэнерго» Южные электрические сети } \\
\text { OJSC “Altaienergo" }\end{array}$ \\
\hline$\wedge 39 / 1-3$ & $\mathrm{~B} \wedge 10 \kappa \mathrm{\kappa} \wedge-12-8$ & $\begin{array}{r}\text { Усть-Калманский } \\
\text { Ust-Kalmanskiy }\end{array}$ & $\begin{array}{r}\text { Э^ектросетевой комплекс № Ю-7 «УСть-Камманский» } \\
\text { фрилиала ОАО «Алтайэнерго» Южные электрические сети } \\
\text { OJSC “Altaienergo" }\end{array}$ \\
\hline$\wedge 40$ & $\mathrm{~B} \wedge 10$ кВ ^-12-9 & $\begin{array}{r}\text { Усть-Калманский } \\
\text { Ust-Kalmanskiy }\end{array}$ & $\begin{array}{r}\text { Электросетевой комплекс № Ю-7 «Усть-Камманский» } \\
\text { фрилиала ОАО «Алтайэнерго» Южные электрические сети } \\
\text { OJSC "Altaienergo" }\end{array}$ \\
\hline$\wedge 42$ & В^ 10 кВ ^-12-9 & $\begin{array}{r}\text { Усть-Калманский } \\
\text { Ust-Kalmanskiy }\end{array}$ & $\begin{array}{r}\text { Электросетевой комплекс № Ю-7 «Усть-Калманский» } \\
\text { фрилиала ОАО «Алтайэнерго» Южные электрические сети } \\
\text { OJSC "Altaienergo" }\end{array}$ \\
\hline$\wedge 43$ & $\mathrm{~B} \wedge 10 \kappa \mathrm{\kappa} \wedge-12-1$ & $\begin{array}{r}\text { Усть-Калманский } \\
\text { Ust-Kalmanskiy }\end{array}$ & $\begin{array}{r}\text { Электросетевой комплекс № Ю-7 «Усть-Калманский» } \\
\text { фрилиала ОАО «Алтайэнерго» Южные электрические сети } \\
\text { OJSC "Altaienergo" }\end{array}$ \\
\hline$\wedge 44 \mathrm{a}$ & $\mathrm{B} \wedge 10 \kappa \mathrm{\kappa} \wedge-12-2$ & $\begin{array}{r}\text { Усть-Калманский } \\
\text { Ust-Kalmanskiy }\end{array}$ & $\begin{array}{r}\text { Электросетевой комплекс № Ю-7 «Усть-Калманский» } \\
\text { фрилиала ОАО «Алтайэнерго» Южные электрические сети } \\
\text { OJSC "Altaienergo" }\end{array}$ \\
\hline$\wedge 44 b$ & $\mathrm{~B} \wedge 10 \kappa \mathrm{\kappa} \wedge-12-2$ & $\begin{array}{r}\text { Усть-Калманский } \\
\text { Ust-Kalmanskiy }\end{array}$ & $\begin{array}{r}\text { Электросетевой комплекс № Ю-7 «Усть-Калманский» } \\
\text { фрилиала ОАО «Алтайэнерго» Южные электрические сети } \\
\text { OJSC "Altaienergo" }\end{array}$ \\
\hline$\wedge 47$ & $\begin{array}{l}\text { В камастре не отмечена } \\
\text { Not listed in the cadaster }\end{array}$ & $\begin{array}{r}\text { Петропав^овский } \\
\text { Petropavlovskiy }\end{array}$ & В кацастре не отмечена / Not listed in the cadaster \\
\hline
\end{tabular}


Табл. 5. Сведения об осмотренных АЭП из кацастровой карты (Окончание).

Table 5. Data on surveyed power lines from the publicly available cadastral map (Ending).

\begin{tabular}{|c|c|c|c|}
\hline 1 & 2 & 3 & 4 \\
\hline$\wedge 48$ & $\begin{array}{l}\text { В каластре не отмечена } \\
\text { Not listed in the cadaster }\end{array}$ & $\begin{array}{l}\text { Петропавловский } \\
\text { Petropavlovskiy }\end{array}$ & В кацастре не отмечена / Not listed in the cadaster \\
\hline$\wedge 49$ & Электросетевой комплекс № Ц-19 & Топчихинский / Topchihinskiy & OAO “МРСК Сибири" / OJSC “MRSK Siberian" \\
\hline опора A & $\mathrm{B} \wedge 10 \kappa \mathrm{K} \wedge-36-2$ & Волчихинский / Volchihinskiy & $\begin{array}{r}\text { Новичихинский электросетевой комплекс № 3-8, на } \\
\text { территории Волчихинского района / Novichiha's Power Grid } \\
\text { Complex № 3-8 }\end{array}$ \\
\hline опора Б & $\mathrm{B} \wedge 10 \kappa \mathrm{\kappa} \wedge-46-2$ & $\begin{array}{l}\text { Красношёковский } \\
\text { Krasnoschyokovskiy }\end{array}$ & $\begin{array}{r}\text { Красношековский электросетевой комплекс фрилиала ОАО } \\
\text { «А^тайэнерго» Южные электрические сети } \\
\text { OJSC “Altaienergo" }\end{array}$ \\
\hline опора C & $\mathrm{B} \wedge 10 \kappa \mathrm{\kappa} \wedge-46-2$ & $\begin{array}{l}\text { Красношёковский } \\
\text { Krasnoschyokovskiy }\end{array}$ & $\begin{array}{r}\text { Красношековский электросетевой комплекс фрилиала ОАО } \\
\text { «Алтайэнерго» Южные электрические сети } \\
\text { OJSC “Altaienergo" }\end{array}$ \\
\hline
\end{tabular}
OJSC "Altaienergo"

Рис. 11. Соотношение гибели птиц на промежуточных и анкерных / угловых опорах.

Fig. 11. Ratio of birds that died on intermediate and push brace electric poles.

\section{Анализ типов опор}

Среди осмотренных опор, под которыми были найдены погибшие птицы, можно вылелить анкерные, угловые и промежуточные опоры. Анкерные и угловые опоры устанавливаются в начале и в конце кинии, в том числе в месте отпайки дочерних миний, и в точках изгиба. Встречаются анкерные и угловые опоры в среднем в соотношении 1:10 к промежуточным, по результатам учётов анкерных опор в $\Delta е-$ сяти осмотренных миниях (^8, ^10, ^15, $\wedge 17, \wedge 20, \wedge 23, \wedge 31, \wedge 38, \wedge 39, \wedge 47)$. ОАнако именно на опоры анкерного и углового типа приходится 22\% всех убитых птиц (рис. 11, внутренняя окружность) вместо ожилаемых 9,1\%, как было бы в случае, если бы интенсивность гибели птиц на анкерных/угловых и промежуточных опорах совпадала. Иначе говоря, учитывая количественное соотношение разных типов опор, одна анкерная/угловая опора уничтожает в 2,9 раза больше птиц, чем одна промежуточная.

Если же рассмотреть только хишных птиц (рис. 11, внешняя окружность), то тут разница будет ешё заметнее - на анкерных опорах погибло 33\% от обшего числа пер-

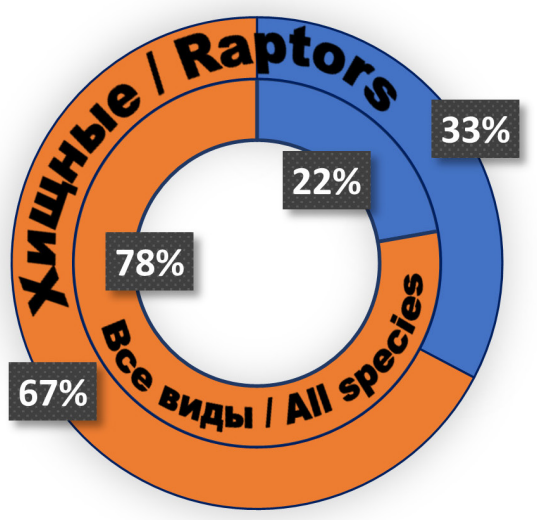

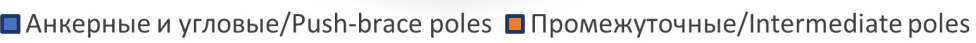

sence while perching on de-energized lines. From this point of view, de-energized lines are much more similar to trees than to live power lines.

While on live power lines a behavioral stereotype helps raptors to survive, which was discussed before.

Eagles form big convocations in Altai Kray during migration season. We observed two of them during the survey. The first one was near the village Kurya - around 30 Steppe, Imperial, and Greater Spotted Eagles, and the second one near the village Krasniye Orlii - about 10 Steppe Eagles. Fortunately, no power lines were in both areas.

Besides raptors, we observed several huge flocks of corvids on the survey route that used wire and poles to spend overnight.

\section{Conclusions}

1. Illegal operation and construction of 6-10 kV power lines without BPDs is still in progress in Altai Kray in violation of environmental laws of Russia.

2. The average bird mortality rate on unsafe power lines in the present study was 5.6 ind./km; solely for raptors $-1.18 \mathrm{ind} . / \mathrm{km}$. This rate is level with the one observed during the breeding season of 2009 (5.15 ind./km).

3. Raptors make $21 \%$ of the total of birds found dead. Endangered species make 1.94\% of the total.

4. The highest density of dead birds was observed on unsafe power lines stretching through open undisturbed habitats - 9.1 ind. $/ \mathrm{km}$ for all species of birds and 2.31 ind./km for raptors. These lines should be retrofitted with bird-protection devices in the first place.

5. The damage to the ecosystem observed during the survey of $91.8 \mathrm{~km}$ of unsafe power lines is equal to 6.125 million Rubles. Or it is similar to 3,925 Rub per one electric pole, which is twice the price of a set of three BPDs 

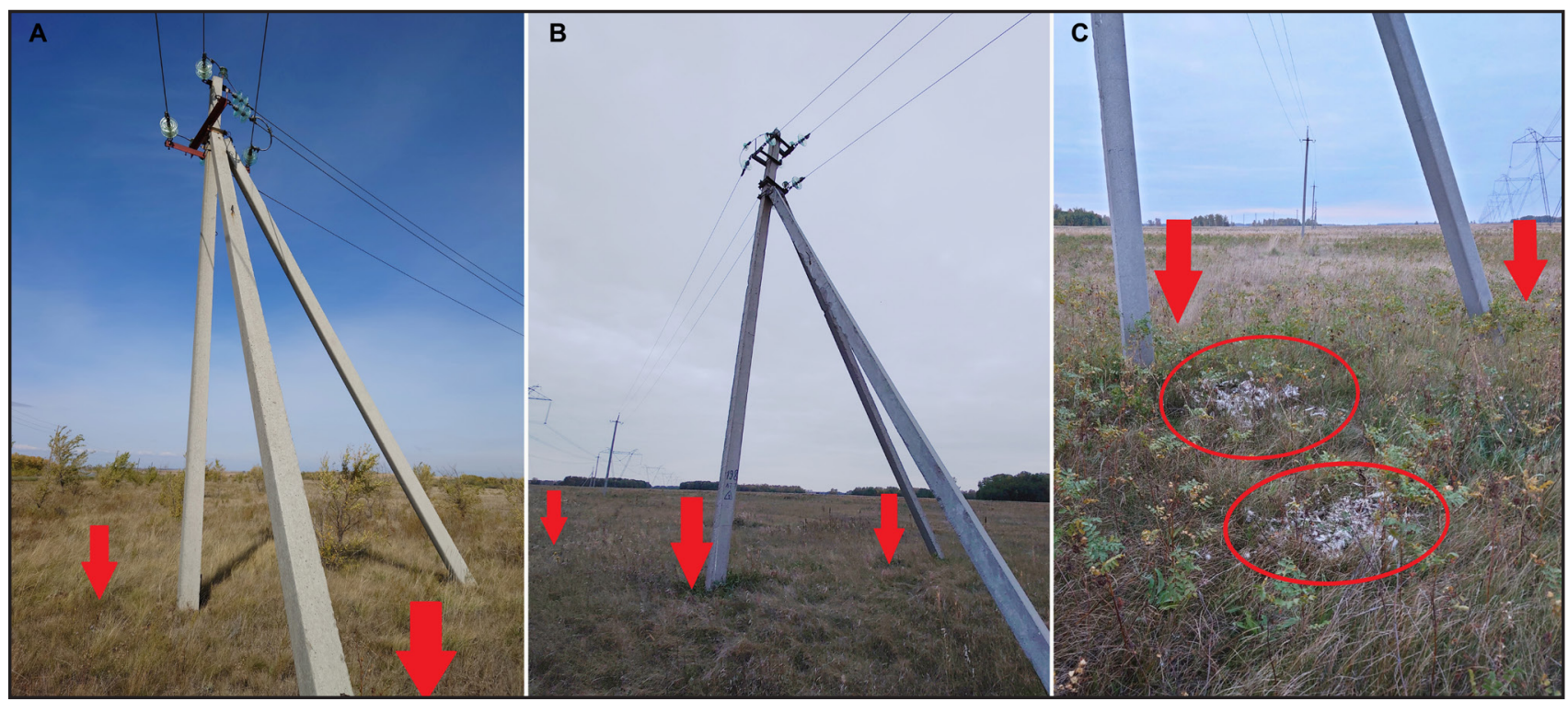

Рис. 12. А - Опора из ПО АЭП ^23, погубившая Авух канюков (Buteo buteo). В - Опора из ПО АЭП ^13, погубившая курганника (Вutео rufinus), канюка и пустельгу (Falco tinnunculus). C - Опора из ПО ^ЭП ^13, погубившая четырёх канюков. Фото Е. Шнайдер.

Fig. 12. A - A pole from the UPL 125 that killed two Common Buzzards (Buteo buteo). B - A pole from the UPL 113 that killed a Long-Legged Buzzard (Buteo rufinus), a Common Buzzard, and a Kestrel (Falco tinnunculus). C - A pole from the UPL 113 that killed four Common Buzzards. Photos by E. Shnayder.

натых хишников. Превышение в 4,9 раза. Этот печальный фракт регулярно находит подтвержление в полях - нередки случаи, когАа под одной анкерной опорой межат

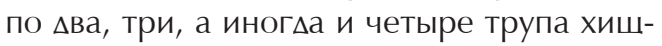
ных птиц (рис. 12).

Опасность анкерных опор состоит в том, что, во-первых, на них намного чаше бывают установлены минейные разъединители (^Р), чем на промежуточных, и они являются наиболее опасными элементами электрической инорраструктуры (рис. 13 а). that are needed to ensure the safety of one electric pole.

6. The estimated number of birds that died on the surveyed power lines during both migrations and nesting period (from April till October) is equal to 792 individuals.

7. Total damage to the ecosystem caused by the whole length of unsafe power lines operating in Altai Kray is hard to estimate. But if at least $10 \%$ of all existing $0.4-35 \mathrm{kV}$ power lines in the region are not safe for birds, then the number of electrocuted birds can reach

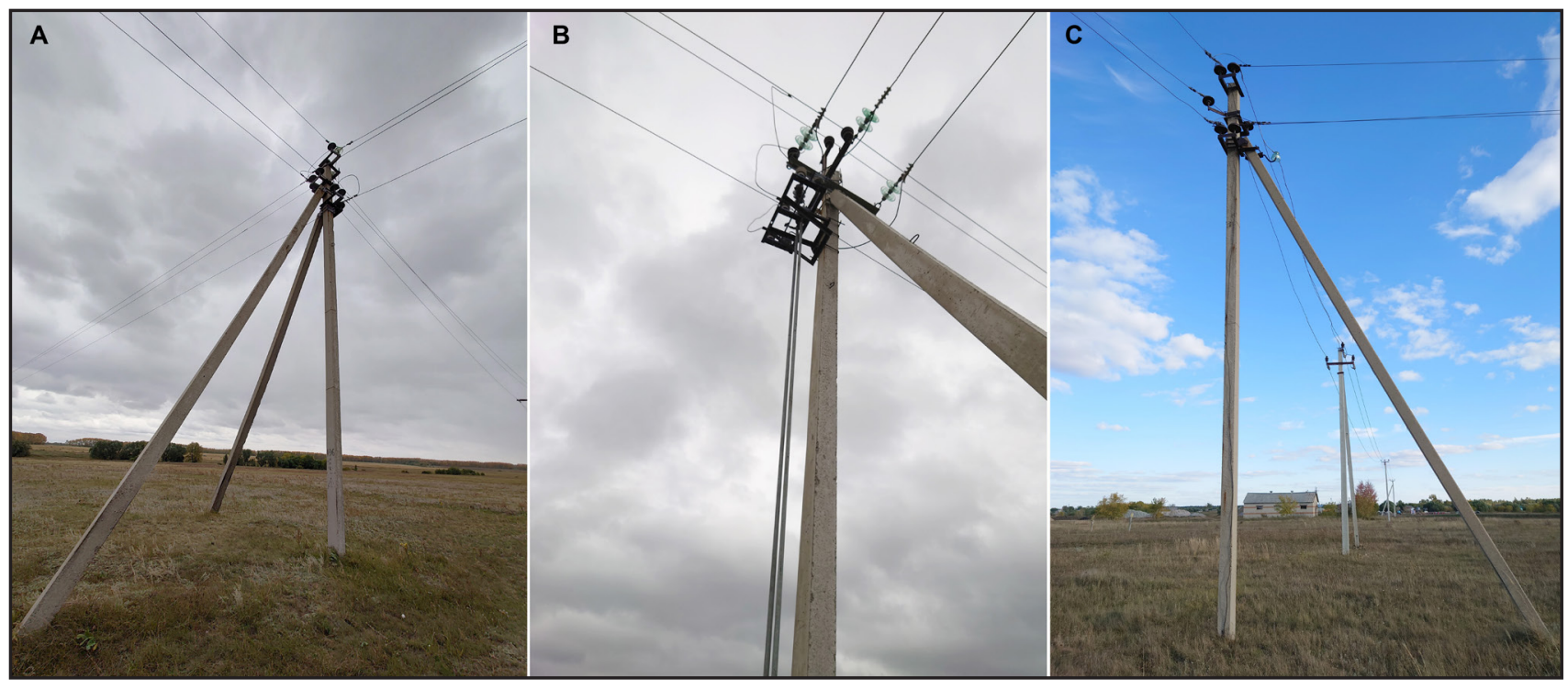

Рис. 13. А - Анкерная опора с линейным разьединителем и исходящей отпайкой. $B$ - Угловая опора с проводами, образуюшими угол, и исходяшей отпайкой. C - Анкерная опора с двумя отпайками. Фото Е. Шнайдер.

Fig. 13. A - A push brace pole with a linear disconnector and a lateral tap line. $B-A$ push brace pole at the bending point of a power line with an outcoming tap line. $C$ - A push brace pole with two outcoming tap lines. Photos by $E$. Shnayder. 
АР представляют собой удобную широкую п^ошаАку м^я посаАки, при этом совершенно не изолированы и находятся очень близко от оголённых проводов. Во-вторых, сами провода на таких конструкциях часто мибо образуют угол, если опора угловая, мибо появляется Аополнительный прово или $\Delta в а$, если опора установлена в месте отпайки Аочерней минии (рис. 13 a, b, с). В обоих случаях расстояние межАу провоАами сокрашается, что увеличивает опасность касания. Повышенная угроза $и я я$ птиц со стороны угловых и анкерных опор отмечалась и ранее (Мацына, Замазкин, 2010; Горошко, 2011; Demeter et al., 2018; Шнайлер и вр., 2020).

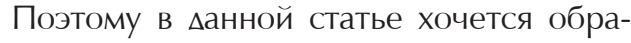
тить особое внимание на необходимость оснашения ПЗУ анкерных опор. К сожалению, в настояшее время наблюдается скорее обратная тенденция - зачастую в линиях, гАе промежуточные опоры несут ПЗУ, анкерные стоят голые, видимо ввиду того, что процесс натягивания на них зашитного кожуха несколько сложнее, чем на рядовую опору. Такими примерами могут служить и миния ^16, и ^22, и ^44а. То есть все ^инии, которые от начала и $\Delta$ конца были оснашены ПЗУ, кроме анкерных опор.

Рацует в Аанном случае то, что пти-

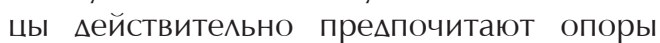
с ПЗУ, и результаты проверки показали, что под незашишёнными анкерами киний, гле промежуточные опоры все оснашены ПЗУ, трупы птиц практически полностью отсутствуют.

\section{Оценка вимового разнообразия погиб- ших на АЭП птиц}

Всего на ПО АЭП были найдены трупы 23 видов птиц. Наиболее часто встречались погибшие серые вороны (Corvus cornix) и грачи (Corvus frugilegus) - суммарно 304 ос., 59\% от обшего числа погибших птиц, и реже - $р$ ругие синантропные виды - сороки (Pica ріса) (39 ос.), галки (Corvus monedula) (23 ос.), скворшы (Sturnus vulgaris) (16 ос.). Среди хишных птиц большинство найденных особей приналмежало к трём видам: чёрный коршун - 33 ос., канюк обыкновенный - 27 ос. и пустельга - 30 ос. Также из хишных регулярно встречались погибшие ястреба-тетеревятники (7 ос.). ОАнажыы встретилась погибшая бородатая неясыть. Остальные виды хишных птиц, найденные погибшими на АЭП во время этой проверки, занесены в фредеральную Красную книгу. Это фрилин - 2 ос., курганник обыкновенный - 2 ос.,
50,700 individuals and the total damage to the ecosystem can reach 603 million Rubles.

8. We observed an increased level of bird mortality on push brace poles compared with intermediate. The excess was 2.9 times considering all species and 4.9 times for raptors. Applying bird-protection devices to pushbrace poles will significantly decrease the mortality rate of birds, especially of raptors.

\section{Recommendations}

To ensure the safety of wildlife during the operation of electrical grid infrastructure as prescribed by clause 28 of the Federal Law on Wildlife N 52-Ф3 from 24.04.1995 (in edition from 11.06.2021), it is required to prevent any possibility of electrocution of birds from contact with exposed parts of electrical equipment. Retrofitting of existing unsafe 6-35 kV power lines with bird-protection devices is considered as a solution. New lines should be designed with bird safety in mind, that can be achieved by using isolated wire, suspension insulators, or wooden poles.

First of all, power line retrofitting should be applied to

1. Push brace poles and poles with linear disconnectors.

2. Power lines stretching through open undisturbed biotopes.

All lines with BPDs should be annually surveyed and broken parts of the protection should be replaced.

\section{Conclusion}

Information about unsafe power lines revealed in the survey was sent to the environmental prosecutor's office of the Altai Kray. We hope the environmental protection is a matter of concernment for the power line owners and they are willing to cooperate in the implementation of bird-protection measures starting with the sites that pose the greatest threat for raptors.

\section{Funding}

This work was carried out thanks to the financial support of readers of the telegram channel "Expeditionary Pictures"16 and the personal contribution of the author.

\section{Acknowledgments}

I am sending heartfelt gratitude to my subscribers who supported this work. I also want to thank State Inspectors of the Ministry of Nature Resources - Evgeniy Berdichevskiy, Anatoly Kostenko, and Aleksey Rybin who provided effective professional support in making incident reports about the facts of electrocution of endangered species. 
сокол-сапсан - 2 ос., степной мунь - 1 ос., степной орёл - 1 ос., большой подорлик - 1 ос. Останки ешё одного орла $\Delta$ о вида определить не удалось. Помимо вышеперечисленных, также были найдены останки тетерева (Tetrao tetrix), большой горлицы (Streptopelia orientalis), трёх сизых голубей

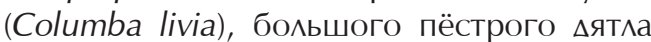
(Dendrocopus major), пяти воронов (Corvus corax) и четырёх представителей мелких воробьинообразных, из которых уда^ось илентиорицировать славку-мельничка (Curruca curruca) и полевого жаворонка (Alauda arvensis). Родовую приналлежность ешё 11 оррагментарных костных останков установить не уда^ось.

Максимальное видовое разнообразие среди погибших птиц было отмечено на степной минии ^13, Алиной 8,6 км - 13 ви$\Delta$ ов. ПоА этой минией также бы^о собрано наибольшее число погибших птиц - 86 особей, хотя по показателю плотности гибели эта миния уступила более коротким участкам ПО ^ЭП. Но эта ^иния стала несомненным анти-лидером по плотности погибших хишных птиц - 4,42 ос./Км, а процент хишных птиц среди всех найьенных на линии трупов состави^ 44,2\%.

Также на полевых миниях $\bigwedge 35$ Алиной 7,22 км и минии $\wedge 6$ Алиной 4,5 км погибло по 10 и 9 видов соответственно. На прочих ПО миниях Алиной более 2 км погибло по
5-7 вичов птиц, на миниях менее 1 км - по 0-4 вида, на миниях от 1 оо 2 км - по 0-7 виАОв птиц (табл. 1).

\section{Учёт живых хишных птиц на АЭП}

Результаты наблюдений живых птиц во время осмотров ПО АЭП приведены в табмице 6.

Всего было отмечено 45 особей пернатых хишников, находяшихся вблизи осматриваемых миний. При этом 31 особь (68.9\%) с инорраструктурой никак не взаимодействовала, предпочитая натуральные присады, такие как деревья, камни, стога сена, мибо вообше пребывая в воздухе. Из оставшихся 14 особей, встречены сидяшими на проводах и изомяторах обесточенной минии, поццерживаемой бетонными опорами (пустельга и орёл-могильник), 7 особей (15,5\%) использовали в качестве присады церевянные опоры (орлы-могильники, орланы-белохвосты, канюк, пустельга, ястреб-перепелятник Accipiter nisus), ешё 4 пустельги (8,9\%) были встречены сидяшими на проводах ПО ^ЭП на бетонных опорах, и ^ишь одна птица - пустельга (2,2\%) использовала изомятор на птицеопасной бетонной опоре в качестве присады.

Совершенно очевиден паттерн избегания миний на бетонных опорах под напряжением у крупных пернатых хишников,

Табл. 6. Встречи живых хишных птиц близ осматриваемых АЭП в сентябре 2021 г. во время проведения исследования.

Table 6. Observations of alive birds of prey in close vicinity of surveyed power lines in September of 2021.

\begin{tabular}{|c|c|c|c|c|c|c|c|c|c|}
\hline \multirow[b]{2}{*}{ Вих / Species } & \multirow[b]{2}{*}{$\begin{array}{r}\text { В воздухе } \\
\text { In air }\end{array}$} & \multirow{2}{*}{$\begin{array}{r}\text { Естественные } \\
\text { присахы } \\
\text { Natural perches }\end{array}$} & $\begin{array}{r}\Delta \text { еревs } \\
\wedge Э П 10 \\
\text { pole of } 10 \mathrm{k} \\
\end{array}$ & $\begin{array}{l}\text { aя опора } \\
\text { Wooden } \\
\text { ower line } \\
\end{array}$ & \multicolumn{3}{|c|}{$\begin{array}{r}\text { Бетонная опора АЭП } 10 \text { кВ } \\
\text { Concrete pole of } 10 \mathrm{kV} \text { power line } \\
\end{array}$} & \multirow[b]{2}{*}{$\begin{array}{r}\text { Всего } \\
\text { Total } \\
\end{array}$} & \multirow[b]{2}{*}{$\begin{array}{l}\text { Аоля, \% } \\
\text { Share, \% }\end{array}$} \\
\hline & & & $\begin{array}{r}\text { Onopa } \\
\text { Pole } \\
\end{array}$ & $\begin{array}{r}\text { Провод } \\
\text { Wire } \\
\end{array}$ & $\begin{array}{r}\text { Tраверса } \\
\text { Cross-arm } \\
\end{array}$ & $\begin{array}{r}\text { Изолятор } \\
\text { Insulator } \\
\end{array}$ & $\begin{array}{r}\text { Провод } \\
\text { Wire } \\
\end{array}$ & & \\
\hline Aquila heliaca & 5 & 4 & 2 & & & $1^{*}$ & & 12 & 26.7 \\
\hline Aquila nipalensis & 1 & & & & & & & 1 & 2.2 \\
\hline Clanga clanga & 3 & & & & & & & 3 & 6.7 \\
\hline Haliaeetus albicilla & & 3 & 2 & & & & & 5 & 11.1 \\
\hline Buteo buteo & & & 1 & & & & & 1 & 2.2 \\
\hline Pernis apivorus & 3 & & & & & & & 3 & 6.7 \\
\hline Pernis ptilorhynchus & 1 & & & & & & & 1 & 2.2 \\
\hline Milvus migrans & 1 & & & & & & & 1 & 2.2 \\
\hline Accipiter nisus & 3 & 1 & 1 & & & & & 5 & 11.1 \\
\hline Circus cyaneus & 3 & & & & & & & 3 & 6.7 \\
\hline Falco peregrinus & & 1 & & & & & & 1 & 2.2 \\
\hline Falco tinnunculus & 1 & 1 & 1 & & & 1 & $4+1^{*}$ & 9 & 20.0 \\
\hline Всего / Total & 21 & 10 & 7 & $\mathbf{0}$ & $\mathbf{0}$ & 2 & 5 & 45 & \\
\hline Аоля, \% / Share, \% & 46.7 & 22.2 & 15.5 & $\boldsymbol{O}$ & 0 & 4.4 & 11.1 & & \\
\hline
\end{tabular}

\section{Примечания / Notes:}

* линия отключена / line de-energized. 


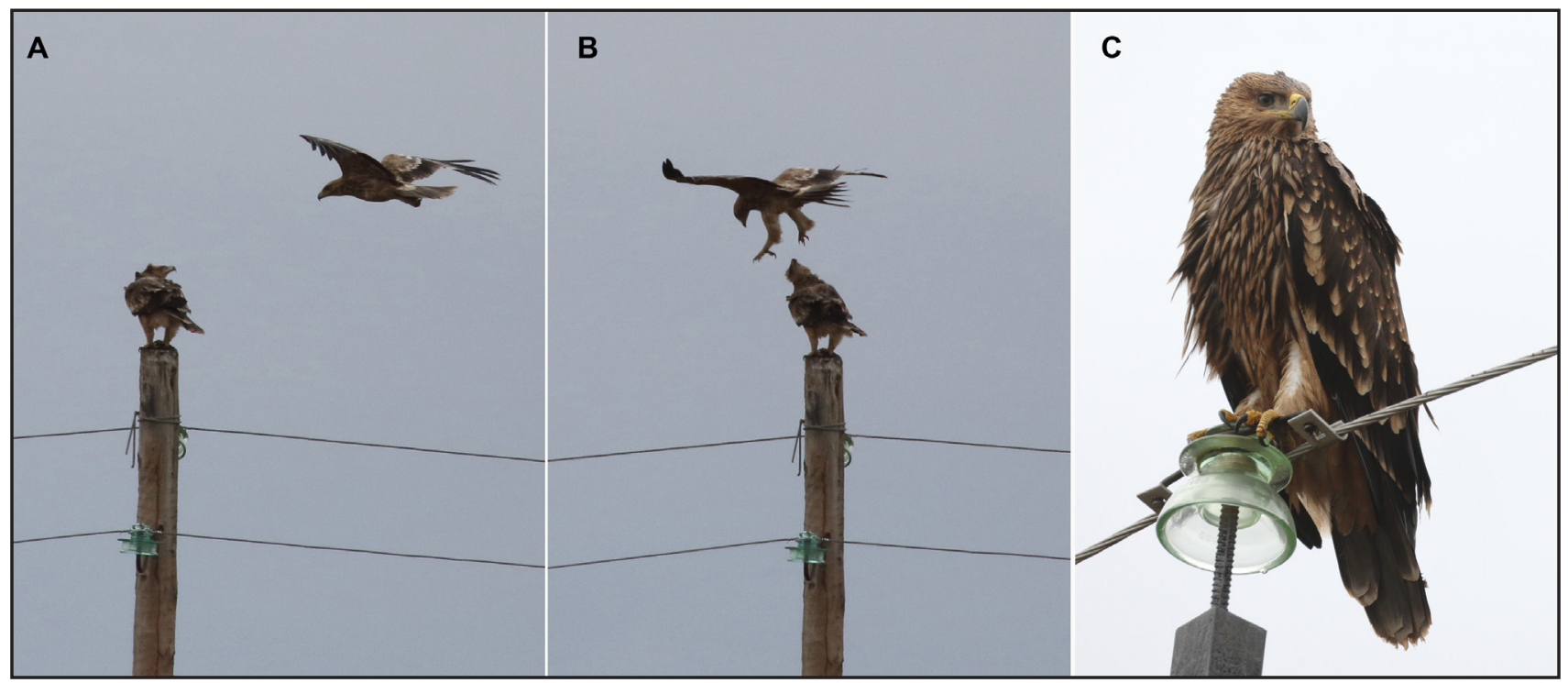

Рис. 14. $A, B-\Delta$ ва орма-могильника (Aquila heliaca) соревнуются за место на безопасной Аеревянной опоре.

РяАом в нескольких Аесятках метров по степи проходит Аиния 113 с густой сетью бетонных опор, но она не привлекает орлов. С - Молодой орёл-могильник, сиАяший на штыревом изоляторе обесточенной минии $\wedge 40$.

Фото Е. Шнайьер.

Fig. 14. $A, B-T w o$ Eastern Imperial Eagles (Aquila heliaca) compete for the place on the safe wooden pole.

A few dozen meters away the UPL 113 runs on concrete poles but it does not attract eagles as a perching site.

$C-A$ juvenile Eastern Imperial Eagle is perching on a pin insulator of a concrete pole of the de-energized power line. Photos by E. Shnayder. таких как орлы-могильники и орланы-бемохвосты. Птицы намеренно выбирают немногочисленные деревянные опоры при изобилии бетонных. Они стараются занять место именно на деревянной опоре и не стремятся занимать пустуюшую бетонную, если место на деревянной занято (рис. 14). В работе наших комег из Оренбургской области (Барбазюк, Петришев, 2011) отмечен аналогичный стереотип: при наличии в АЭП опасных бетонных опор с метамииескими траверсами и безопасных Аеревянных безтраверсных, степные орлы предпочитают в качестве присаА вершины меревянных опор. При этом осмотр обесточенных миний показывает, что на них орлы не $е$ елют выбора межлу типами опор и с одинаковой охотой используют и бетонные, и деревянные (И.В. Карякин, мичн. сообш.). В нашем исследовании единственный орёл, встреченный сидяшим на ^ЭП за всё время проверки, использовал именно обесточенную кинию (рис. 14 с). Как мы уже замечали ранее (Шнайьер и мр., 2020), у хишных птиц орормируется паттерн избегания птицеопасных миний, полАерживаемый отбором.

В статье 2020 г. (Шнайлер и мр., 2020) мы уже обсужАали возможный механизм фрормирования такого паттерна поведения: опоры служат фрактором отбора - выживают те особи, которые используют м^я приса $\Delta$ еревянные опоры, а не бетонные с метамическими траверсами. Хочется $\Delta \mathrm{O}^{-}$ бавить ешё одну гипотезу: птицы видят минии, находяшиеся под напряжением. Аостоверно установлено, что птицы могут видеть направление и чувствовать напряжённость магнитного поля Земли, и известен механизм рецепции, связанный с пигментом, находяшемся в глазу и магниточувствительными клетками в клюве (Wiltschko, Wiltschko, 2019). Возможно, что птицы просто ошушают магнитные поля миний под напряжением и учитывают их отсутствие у обесточенных миний. С такой точки зрения, минии без напряжения больше напоминают меревья и мругие естественные присады, чем минии пол напряжением. На рабочих же миниях избегать гибели птицам помогает поведенческий стереотип, о котором мы рассужьали выше.

В сезон миграции на территории края образуются крупные скопления пролётных

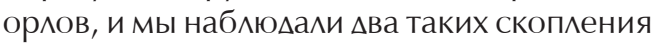

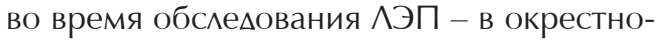
стях с. Курья (около 30 особей степных ор^ов, орлов-могильников и больших подормиков) и близ с. Красные орлы (около 10 особей степных орлов). К счастью, вблизи от мест скоп^ения не проходи^о ни одной ПО ^ЭП.

Помимо хишных птиц, близ осмотренных миний отмечены несколько очень крупных скоплений врановых, используюших провоАа миний Аля ночёвок.

\section{Выводы}

1. На территории А^тайского края проАолжается незаконная эксплуатация птицеопасных ^ЭП 6-10 кВ без птицезашитных устройств.

2. Средняя плотность гибели птиц на

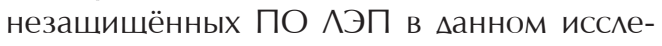
Аовании составияа 5,6 ос./Км, а плотность гибели хишных птиц - 1,18 ос./км. Это сопоставимо с уровнем гибели птиц, выявленным в гнезАовой период в 2009 году $-5,15$ ос./Км. 
3. Погибшие хишные птицы в нашем исследовании составили 21\% от обшего числа най енных останков, а вилы, внесённые в Красную книгу РФ, - 1,94\%. В работе 2009 года эти показатели могли быть рассчитаны мишь суммарно мля Алтайского края и Республики Алтай и составляют мля хишных птиц - 28,5\%, Аля виАОв из КК РФ - 5,6\%. Сравнивать эти показатели с полученными в 2021 году в А^тайском крае будет некорректно, ввичу более высокой плотности обитания крупных пернатых хишников в Республике Алтай.

4. Максимальная плотность гибели птиц была выявлена на ПО ^ЭП, идуших через открытые ненарушенные биотопы - 9,1 ос./км Аля всех виАОв и 2,31ос./км $\Delta$ оя хишных птиц. Именно эти участки Аолжны быть оснашены ПЗУ в первую очередь.

5. Ушерб от фрактической гибели птиц на осмотренных 91,8 км незашишённых ПО АЭП в ^иниях с ПЗУ составил в рублёвом эквиваленте 6,125 млн. руб. Что аналогично 3925 руб. на одну опору. А это как минимум в 2 раза больше, чем стоимость 3-х комплектов ПЗУ на одну промежуточную опору ${ }^{33}$.

6. Вероятный уровень гибели птиц на проверенных ПО АЭП за миграционногнезАовой сезон с апреля по октябрь оценён в 792 особи.

7. Обший ушерб на всех ПО ^ЭП А^тайского края точно оценить невозможно, но если Аопустить, что ПО АЭП составляют хотя бы $10 \%$ от суммарной Амины миний 0,4-35 кВ в крае, то гибель птиц с апреля по октябрь в А^тайском крае может Аостигать 50700 особей, а ушерб - 603 м^н. руб.

8. Отмечен повышенный уровень гибеми птиц на анкерных и угловых опорах по сравнению с промежуточными. Суммарно м^я всех видов птиц превышение состав^яет 2,9 раза, а м^я хишных птиц - 4,9 раза. Первоочередная установка зашиты на таких опорах сушественно повысит уровень безопасности м^я птиц, особенно хишных.

\section{Рекомендации}

$\Delta \wedge я$ обеспечения безопасности объектов животного мира при эксплуатации АЭП, в соответствии с требованиями статьи 28 Федерального закона от 24.04.1995 N 52-Ф3 (реА. от 11.06.2021) «О животном мире» (с изм. и АОп., вступ. в силу с 01.08.2021), необходимо исключить возможность гибели птиц вследствие их кон- такта с неизолированными частями электрооборудования. $\Delta \wedge я$ этого возможно оснашение сушествуюших 6-35 кВ ^ЭП на бетонных опорах со штыревыми изо^яторами специальными птицезашитными устройствами. При проектировании новых 6-35 кВ киний обеспечить безопасность животных возможно либо использованием изолированного провода СИП-3, мибо полвесных изоляторов, мибо деревянных безтраверсных опор.

Первоочередного переоснашения требуют:

1. Анкерные и угловые опоры, а также опоры с линейными разъединителями.

2. Аинии, проходяшие через открытые ненарушенные местообитания.

$\Delta \wedge я$ миний с установленными ПЗУ необходимо ежегодно прово иить обследование их состояния и своевременно осушеств^ять их ремонт и замену.

\section{Заключение}

Инорормация о птицеопасных АЭП была передана в природоохранную прокуратуру А^тайского края. Мы надеемся на заинтересованность в сохранении природы и готовность к сотрудничеству со стороны собственников миний и реализацию птицезашитных мероприятий, начиная с участков, представляюших максимальную угрозу пернатым хишникам.

\section{Финансирование}

$\Delta$ анная работа выполнена благодаря фринансовой подмержке читателей телеграмканала «Экспедиционные картинки» ${ }^{34}$ и мичным средствам автора.

\section{Благодарности}

Серцечно благодарю подписчиков моего телеграм-канала, оказавших фринансовую поццержку этому исследованию. Также выражаю благодарность гос.инспекторам Управления охотхозяйства Министерства природных ресурсов и экологии Алтайского края Бердичевскому Евгению Михайловичу, Костенко Анатолию Анатольевичу и Рыбину Алексею Анатольевичу, благодаря оперативности которых удава^ось быстро актировать фракты гибели видов, занесённых в Красную книгу РФ.

\section{Аитература}

Барбазюк Е.В., Петришев В.П. Оценка гибе^и птиц на миниях электропередач 6-10 кВ в Оренбургской области летом 2011 года. - Вестник ОГУ. 2011. № 12. С. 31-33. [Barbazyuk E.V., Petrischev V.P. Estimation of bird deaths on power 
lines $6-10 \mathrm{kV}$ in the Orenburg region in summer 2011. - Bulletin of the Orenburg State University. 2011. 12: 31-33. (in Russian).] URL: http://rrrcn. ru/wp-content/uploads/2014/12/9.pdf Аата обрашения: 20.12.2021.

Важов С.В. Экология и распространение соколообразных и совообразных в предгорьях А^тая. Автореорерат ииссертации на соискание ученой степени кандидата биологических наук. Барнаул: Алтайский государственный университет, 2012. 22 с. [Vazhov S.V. Ecology and distribution of birds of prey and owl in the foothills of the Altai. Abstract of thesis. Barnaul, 2012: 1-22. (in Russian).] URL: https://www.asu.ru/files/ documents/00005483.pdf $\triangle$ ата обрашения: 20.12.2021.

Горошко О.А. Гибель птиц на АЭП в Ааурской степи (Юго-Восточное Забайкалье), Россия. Пернатые хишники и их охрана. 2011. № 21. C. 84-99. [Goroshko O.A. Bird Electrocution in the Daurian Steppe (South-Eastern Trans-Baikal Region), Russia. - Raptors Conservation. 2011. 21: 84-99.] URL: http://rrrcn.ru/ru/archives/15240 Аата обрашения: 20.12.2021.

Инорляция в России. 2021. [Inflation in Russia. 2021.] URL: https://xn----ctbjnaatncev9av3a8f8b. xn--p1ai Аата обрашения: 20.12.2021.

Карякин И.В. Пернатые хишники в электросетевой среде Северной Евразии: каковы перспективы выживания? - Пернатые хишники и их охрана. 2012. № 24. C. 69-85. [Karyakin I.V. Birds of Prey and Power Lines in Northern Eurasia: What are the Prospects for Survival? - Raptors Conservation. 2012. 24: 69-85.] URL: http:// rrrcn.ru/ru/archives/12320 Аата обрашения: 15.12.2021.

Карякин И.В., Николенко Э.Г., Важов С.В., Бекмансуров P.X. Гибель пернатых хишников

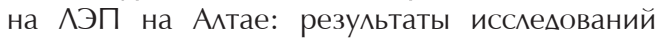
2009 года, Россия. - Пернатые хишники и их охрана. 2009. № 16. C. 45-64. [Karyakin I.V., Nikolenko E.G., Vazhov S.V., Bekmansurov R.H. Raptor Electrocution in the Altai Region: Results of Surveys in 2009, Russia. - Raptors Conservation. 2009. 16: 45-64.] URL: http://rrrcn.ru/ru/archives/19496 Аата обрашения: 20.12.2021.

Карякин И.В., Николенко Э.Г., ШнайАер Е.П. Обследован проектируемый заказник «Северный фрас А^тая». - Российская сеть изучения и охраны пернатых хишников. 2017. [Karyakin I.V., Nikolenko E.G., Schnayder E.P. An examination of projected wildlife sanctuary "Northern face of Altai". - Russian Raptor Research and Conservation Network. 2017.] URL: http://rrrcn.ru/archives/30224 Аата обрашения: 20.12.2021.

Карякин И.В., Николенко Э.Г., Шнайлер Е.П., Зиневич А.С., Пуликова Г.И., Бартошук К., Хорват М., Юхаш Т., Агабабян К., Аньреенкова Н.Г. Результаты GPS/GSM-трекинга ювенильных степных орлов из России и Казахстана. - Пернатые хишники и их охрана. 2019. № 39. С. 71-227. [Karyakin I.V., Nikolenko E.G., Shnayder E.P., Zinevich L.S., Pulikova G.I., Bartoszuk K., Horvath M., Juhász T., Aghababyan K., Andreenkova N.G. Results of the GPS/GSM-Tracking of Juvenile Steppe Eagles from Russia and Kazakhstan. - Raptors Conservation. 2019. 39: 71-227.] DOI: 10.19074/18148654-2019-39-71-227 URL: http://rrrcn.ru/ru/archives/33119 Аата обрашения: 20.12.2021.

Карякин И.В., Смелянский И.Э., Бакка С.В., Грабовский М.А., Рыбенко А.В., Егорова А.В. Крупные пернатые хишники Алтайского края. - Пернатые хишники и их охрана. 2005. № 3. C. 28-51. [Karyakin I.V., Smelansky I.E., Bakka S.V., Grabovsky M.A., Rybenko A.V., Egorova A.V. The Raptors in the Altai Kray. - Raptors Conservation. 2005. 3: 28-51.] URL: http://rrrcn.ru/en/archives/31422 Аата обрашения: 20.12.2021.

Мацына А.И., Замазкин А.Е. Рекоменьации по обеспечению безопасности объектов животного мира при эксплуатации воздушных миний связи и электропередачи на территории Нижегородской области. Нижний Новгород, 2010. 60 c. [Matsyna A., Zamazkin A. Recommendations on ensuring the safety of wildlife during the operation of overhead power and communication lines in the territory of the Nizhny Novgorod district. Nizhny Novgorod, 2010: 1-60. (in Russian).] URL: http://rrrcn.ru/ru/archives/12296 Аата обрашения: 20.12.2021.

Методика исчисления размера вреда, причинённого объектам животного мира, занесённым в Красную книгу РФ, а также иным объектам животного мира, не относяшимся к объектам охоты и рыболовства и среде их обитания от 28.04.2008 № 107 с изменениями от 12.12.2012 № 429. [The Methodology for Estimating the Level of Damage Caused to Species Listed in the Red Data Book of Russian Federation, as Well as to Non-Game Species and their Habitats (Approved by decree of the Ministry of Natural Resources of Russia from 28/04/2008 No. 107 as amended on 12.12.2012 No. 429.) (in Russian).] URL: https://base.garant.ru/12161284/53f89421 bbdaf741eb2d1ecc4ddb4c33 Аата обрашения: 20.12.2021.

Методика исчисления размера вреда, причинённого охотничьим ресурсам от 08.12.2011 № 948, с изменениями от 22.07.2013 № 252 и 17.11.2017 № 612. [The Methodology for Estimating the Level of Damage Caused to Game Species (Approved by decree of the Ministry of Natural Resources of Russia from 08/04/2008 No. 107 as amended on 22/07/2013 No. 252 and 17/11/2017 No. 612.) (in Russian).] URL: http://base.garant. ru/70132926 Аата обрашения: 20.12.2021.

Николенко Э.Г., Карякин И.В. Птишы и АЭП в А^тае-Саянском регионе: масштаб проблемы и пути решения. - Пернатые хишники и их охрана. 2012. № 24. C. 88-97. [Nikolenko E.G., Karyakin I.V. Birds and Power Lines in the Altai-Sayan Region: The Scale of the Problem and Ways to Address it. - Raptors Conservation. 2012. 24: 88-97.] URL: http://rrrcn.ru/ru/archives/12326 Аата обрашения: 20.12.2021.

Постановление ААминистрации А^тайского края № 418 от 12 августа 2013 года «Об утвержцении схемы развития и размешения особо охраняемых природных территорий А^тайского края на перио $\Delta$ о 2025 года» (с изменениями 
на 31 марта 2021 гола) (в реА. Постановления Алминистрации Алтайского края от 24.07.2015 № 305, Постановлений Правительства А^тайского края от 10.05.2018 № 158, от 06.05.2020 № 204, от 18.01.2021 № 2, от 31.03.2021 № 101). [Resolution of the Administration of the Altai Kray No. 418 of August 12, 2013 "On approval of the scheme for the development and placement of specially protected natural areas of the Altai Kray for the period up to 2025" (as amended on March 31,2021 ) (as amended by the Resolution of the Administration of the Altai Kray of 24.07.2015 No. 305, Resolutions of the Government of the Altai Kray of 05/10/2018 No. 158, of 05/06/2020 No. 204, of 01/18/2021 No. 2, of 03/31/2021 No. 101).] URL: https://docs.cntd.ru/document/460155163 $\triangle$ Ата обрашения: 20.12.2021.

Пуликова Г.И., Воронова В.В. Гибель орлов на воздушных миниях электропередачи в Казахстане: обзор актуального состояния проблемы. - Пернатые хишники и их охрана. 2018. Спецвып. 1. C. 189-191. [Pulikova G.I., Voronova V.V. Death of Eagles on Overhead Power-lines in Kazakhstan: Review of the Actual State of the Issue. - Raptors Conservation. 2018. Suppl. 1: 182-183.] URL: http://rrrcn.ru/ru/archives/32711 $а$ ата обрашения: 20.12.2021.

Салтыков А.В. Основы орнитологической безопасности электросетевой среды. - Бранта. Вып. 17. 2014. C. 153-160. [Saltykov A.V. Fundamentals of ornithological safety in the power grid environment. - Branta. Vol.17. 2004: 153-160. (in Russian).] URL: https://branta.org.ua/ branta-pdf/17/12 saltykov.pdf Аата обрашения: 20.12.2021.

Смелянский И.Э., Томиленко А.А. Пернатые хишники степных предгорий Русского А^тая: находки 2005 года. - Пернатые хишники и их охрана. 2005. № 3. С. 52-53. [Smelansky I.E., Tomilenko A.A. The raptors in the steppe of the Russian Altai foothills - records 2005. - Raptors Conservation. 2005. 3: 52-53.] URL: http://rrrcn.ru/en/ archives/31425 Аата обрашения: 20.12.2021.

Указ губернатора А^тайского края «Об утвержлении схемы и программы «Развитие электроэнергетики Алтайского края» на 2019-2023 годы» № 61 от 28 апреля 2018 гола. Барнаул, 2018. [Decree of the Governor of the Altai Territory "On approval of the scheme and program Development of the Altai electric power industry for 2019-2023" № 61 dated April 28, 2018. Barnaul, 2018. (in Russian).] URL: http://pravo.gov. ru/proxy/ips/?docbody $=\&$ prevDoc $=168111515$ \&backlink $=1 \& \& n d=168107597 \& r d k=0 \&$ refo $\mathrm{id}=168113244$ Аата обрашения: 20.12.2021.

Фелеральный закон от 24.04.1995 № 52-Ф3 (реА. от 11.06.2021) «О животном мире» (с изм. и Аоп., вступ. в силу с 01.08.2021). [Federal Law of the Russian Federation on Wildlife No. 52FZ of 24.04.1995 (edited on 11.06.2011) with amendments]. URL http://www.consultant.ru/ document/cons_doc_LAW_6542/ Аата обраше-

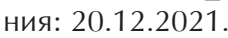

Шнайдер Е.П., Николенко Э.Г., Карякин И.В. Гибель птиц на АЭП в Хакасии (Россия) в 2020 году. - Пернатые хишники и их охрана. 2020. № 41. C. 26-63. [Shnayder E.P., Nikolenko E.G., Karyakin I.V. Electrocutions of Bids on Power Lines in the Khakassia Republic, Russia, in 2020. - Raptors Conservation. 2020. 41: 26-63.] DOI: 10.19074/1814-8654-2020-41-26-63 URL: http:// rrrcn.ru/ru/archives/33844 Аата обрашения: 20.12.2021.

Demeter I., Horvath M., Nagy K., Gorogh Z., Toth P., Bagyura J., Solt S., Kovacs A., Dwyer J.F., Harness R.E. Documenting and reducing avian electrocutions in Hungary: A conservation contribution from citizen scientists. - The Wilson Journal of Ornithology. 2018. 130(3): 600-614. DOI: 10.1676/17-031.1 URL: https://www.researchgate. net/publication/328546978 $\triangle$ ата обрашения: 20.12.2021.

Lehman R.N., KennedyP.L., SavidgeJ.A. The state of the art in raptor electrocution research: a global review. - Biological Conservation. 2007. 136(2): 159-174. DOI: 10.1016/j.biocon.2006.09.015 URL: http://www.globalraptors.org/grin/researchers/uploads/531/global review 2007.pdf $\Delta$ Ата обрашения: 20.12.20르.

Loss S.R., Will T., Marra P.P. Refining estimates of bird collision and electrocution mortality at power lines in the United States. - Plos One. 2014. 9(7): e101565. DOI: 10.1371/journal. pone.0101565 URL: https://journals.plos.org/plosone/article?id=10.1371/journal.pone.0101565 Аата обрашения: 20.12.2021.

Prinsen H.A.M., Smallie J.J., Boere G.C., Píres N. (Compilers). Guidelines on How to Avoid or Mitigate Impact of Electricity Power Grids on Migratory Birds in the African-Eurasian Region. AEWA Conservation Guidelines No. 14, CMS Technical Series No. 29, AEWA Technical Series No. 50, CMS Raptors MOU Technical Series No. 3, Bonn, Germany, 2012: 1-45. URL: https://www.cms.int/sites/default/files/ publication/ts50_electr_guidelines_03122014.pdf Аата обрашения: 20.12.2021.

RRRCN. Изучение миграций степных орлов из А^тае-Саянского региона России и Центрального Казахстана в 2018-2019 гг. - Российская сеть изучения и охраны пернатых хишников. 2021 а. [RRRCN. Research of the Steppe Eagles migration from the Altai-Sayan region of Russia and Central Kazakhstan in 2018-2019. - Russian Raptor Research and Conservation Network. 2021 a.] URL: $\quad$ http://rrrcn.ru/ru/migration/se2018 Аата обрашения: 20.12.2021.

RRRCN. Изучение миграций степных орлов из Алтае-Саянского региона России в 2020-2021 гг. - Российская сеть изучения и охраны пернатых хишников. 2021 b. [RRRCN. Research of the Steppe Eagles migration from the Altai-Sayan region of Russia in 2020-2021. - Russian Raptor Research and Conservation Network. 2021 b.] URL: http:// rrrcn.ru/ru/migration/se2020 $\Delta$ ата обрашения: 20.12.2021.

Wiltschko $R$, Wiltschko W. Magnetoreception in birds. - Journal of the Royal Society, Interface. 2019. 16(158): 20190295. DOI: 10.1098/rsif.2019.0295 URL: https://royalsocietypublishing.org/doi/10.1098/ rsif.2019.0295 Аата обрашения: 20.12.2021. 